\title{
NALAR HUKUM IMAM SHÂFI'Î TENTANG USIA KEDEWASAAN DALAM HAK IJBÂR; REKONTRUKSI DALAM KONTEKS KE- INDONESIAAN
}

\author{
Moch. Aufal Hadliq Khaiyyul Millati Waddin \\ Universitas Hasyim Asy'ari Tebuireng Jombang, Indonesia \\ E-mail: hadliqaufal@gmail.com
}

\begin{abstract}
The right $\ddot{y} b a \hat{r}$ is the right of father or grandfather to marry off his daughter without having to get permission from the daughter to be married, provided that she is not a widow. When Shâfiri established the law of the right $\ddot{y b a ̂ r}$, the social condition of the woman was only domestic at the time. In contrast to now, they have started to spread in the public domain. Focus of this research is the reasoning of Shâfiî law regarding the rights of marriage guardian ÿbâr and its reconstruction in the context of Indonesia. Using the sociology and history approach with the category of normative legal research in the form of library research. A father or grandfather is forbidden to force girls in the realm of marriage. Because it contains the benefit, that is to protect religion, soul, mind, property and honor. As well as women's habits are different. Age of Shâfî̀, even to the beginning of Indonesian independence only live to become domestic. Now, it is allowed to follow education, have a position even work. This opinion is in accordance with the rules of la yunkar taghanyur al-abkâm bi taghayyur al-asman, and reinforced by the method maslahah and 'uff.
\end{abstract}

Keywords: Reconstruction, Reason of Law, Right Ijbâr, Guardian Marriage.

\section{Pendahuluan}

Permasalahan yang sering memunculkan kontroversi adalah isu-isu tentang perempuan, bahkan kalangan modemis menyatakan perlunya rekonstruksi nalar hukum untuk menjawab persoalan. Beberapa jawaban yang telah terlontar selama ini temyata belum memberikan kepuasan, justru memicu ketidakpuasan. Bisa dikatakan bahwa isu perempuan dalam Islam merupakan masalah yang kompleks, karena ia tidak sekedar persoalan yang hanya bisa didekati dengan pemaparan final dari doktrindoktrin kegamaan, akan tetapi juga harus memperhatikan sejarah sosial, teologi ataupun sensifitas gender. Pada dasarnya, akar dari semua persoalan itu berasal dari ide tentang emansipasi wanita.

Di Negara Indonesia, pemerintah memberikan perhatian lebih terhadap perempuan dan anak. Usaha yang dilakukan adalah diterapkannya beberapa 
peraturan, seperti UU No. 25 Tahun 2000 tentang Program Pembangunan Nasional (Propenas), Keppres No. 163 Tahun 2000 tentang Pengkoordinasian dan Penggerakan Upaya-Upaya Pembangunan di Bidang Pemberdayaan Perempuan dan Kesejahteraan dan Perlindungan Anak, Inpres No. 9 Tahun 2000 tentang Pengarusutamaan Gender dalam Pembangunan Nasional. Untuk mengimplementasikan komitmen di atas, maka disusun Rencana Setrategis (Renstra) Kantor Meneg Pemberdayaan Perempuan Tahun 2001-2004. Renstra ini berisi tentang kebijakan, strategi, program dan kegiatan yang akan dilaksanakan selama empat tahun (2001-2004). ${ }^{1}$

Upaya lainnya yang dilakukan pemerintah dalam mewujudkan keadilan dan kesetaraan gender adalah dengan diajukannya beberapa RUU oleh Kantor Menteri Negara Pemberdayaan Perempuan, untuk dilakukan revisi. Menurut Sri Redjeki Sumaryoto, Meneg Pemberdayaan Perempuan, sekarang ini ada sekitar 40 peraturan perundangan yang diusulkan pihaknya untuk direvisi. Usulan revisi ini disampaikan, karena produk perundang-undangan tersebut bias gender. Diantaranya adalah Kitab Undang-Undang Hukum Pidana (KUHP), UU No. 62 Tahun 1958 tentang Kewarganegaraan, UU No. 1 Tahun 1974 tentang Perkawinan, UU No. 8 Tahun 1981 tentang Kitab Undang-Undang Hukum Acara Pidana (KUHAP), UU No. 2 Tahun 1989 tentang Sitem Pendidikan Nasional, dan UU No. 3 Tahun 1992 tentang Jaminan Sosial Tenaga Kerja (Jamsostek). Selain usulan revisi, sejumlah RUU Perlindungan Anak dan RUU Kesetaraan Gender yang telah menjadi usul inisiatif DPR. Selain itu juga ada RUU Anti Kekerasan Dalam Rumah Tangga (AKDRT).

Seiring dengan itu, setelah 24 tahun rentang waktu dari disahkannya UU No. 1 Tahun 1974 dan 11 tahun dari ditetapkannya KHI Menteri Agama lewat pertemuannya dengan para tokoh agama (ulama atau pakar) beserta dengan KetuaKetua PTA se-Indonesia pada hari kamis, 19 September 2002, mengatakan akan mengajukan tiga Rancangan Undang-Undang (RUU) ke DPR RI untuk direvisi. Ketiga RUU tersebut adalah RUU Perkawinan Islam, RUU Kewarisan Islam dan RUU Wakaf Islam. ${ }^{2}$

Salah satu tuntutan emansipasi wanita adalah ide tentang perlindungan hak reproduksi perempuan disepakati pada konferensi dunia tentang kependudukan dan perempuan (ICPD) yang diadakan di Kairo pada 1994, yang menyepakati bahwa perempuan memiliki hak reproduksinya sendiri yang harus dijaga dan dipelihara. Salah satu tuntutan hak reproduksi tersebut adalah hak perempuan untuk menentukan

\footnotetext{
${ }_{1}^{1}$ Zaitunah Subhan, Peningkatan Kesetaraan \& Keadilan Jender Dalam Membangun Good Govermance (Jakarta: elKahfi, 2002), 2-4.

2 Iskandar Ritonga, Hak-Hak Wanita dalam Putusan Peradilan Agama (Jakarta: Program Peningkatan Kualitas Pelayanan Publik Ditjen Bimas Islam dan Penyelenggaraan Haji, 2005), 153.
} 
pasangan hidupnya sendiri. ${ }^{3}$ Dalam pandangan Islam klasik, hal tersebut dibatasi oleh konsep ̈̈bâr yang dipahami oleh masyarakat Indonesia sebagai kawin paksa.

Implikasi dari konsep j̈bâr adalah seorang anak tidak bisa menentukan apa-apa, sehingga gadis yang akan dikawinkan mungkin tidak mengenal wajah calon suaminya hingga hari perkawinannya. Akan tetapi karena pengaruh modernitas, hak ÿbâr kini mulai memudar. Hanya masyarakat tertentu saja yang masih memegang teguh dan melaksanakan konsep j̈bâr dengan bersandar pada dogma-dogma agama. Namun dewasa ini perlu adanya upaya verifikasi ${ }^{4}$ terhadap konsep $\ddot{j} b a \hat{r}$, karena masih didapati pemahaman yang berbeda dikalangan ulama' dalam memahami nas yang dijadikan argumen konsep ini. ${ }^{5}$

Perlu diketahui konsep j̈bâr yang telah dirumuskan oleh Imam Shâfiî adalah produk hukum pada tahun $\pm 200 \mathrm{H}$, yaitu masa kekuasaan bani Abbasiyah. Di mana waktu itu dikatakan oleh sejarahwan sebagai zaman keemasan Islam, terutama dalam bidang ilmu pengetahuan. Penerjemahan terhadap hasil karya pada masa Khalifah Harun al-Rasyid yang kemudian dilanjutkan oleh Khalifah al-Ma'mun. Karya-karya Yunani yang diterjemahkan tersebut meliputi berbagai disiplin, namun sayang kemajuan tersebut kurang diimbangi dengan pemberian ruang bagi perempuan untuk mengaktualisasikan dirinya.

Seiring dengan perkembangan peradaban dan perubahan sosial yang terus bergerak pada ranah global dan mondial, peran kaum perempuan semacam itu agaknya sudah jauh mengalami pergeseran. Asumsi ini diperkuat dengan gencamya perjuangan kaum perempuan dalam upaya melakukan pembebasan "mitos" lama, emansipasi wanita, dan kesetaraan gender. Saat ini perempuan telah terlibat aktif dalam membangun bangsa dan negara melalui dunia politik, ekonomi, sosial, budaya, pendidikan, bahkan keamanan. Kini wilayah-wilayah tersebut tidak hanya didominasi oleh kaum pria, wanita pun turut andil di dalamnya. Bahkan kadang kaum wanita bisa tampil lebih mandiri, dinamis, kreatif, penuh inisiatif, dan profesional dalam mengambil perannya tersebut. ${ }^{6}$

Fungsi ekonomi keluarga kini juga tidak hanya menjadi monopoli laki-laki (suami), melainkan juga perempuan (istri). Penghasilan istri juga tidak sekedar menjadi sumber ekonomi tambahan atau sampingan, tetapi sudah menjadi sumber pokok atau utama. Bahkan, kini semakin banyak terjadi penghasilan istri justru menjadi tumpuan ekonomi keluarga, termasuk untuk suaminya. Para istri tidak hanya duduk di rumah

\footnotetext{
3 Taufiq Hidayat, 'Rekonstruksi Konsep Ijbar”, dalam De Jure Jumal Syariah Dan Hukum, Vol. I, No. 1 Agustus 2009, STAI An-Nawawi Purworejo, 11.

${ }_{4}^{4}$ Pembuktian kebenaran. Pius A Partanto dan M Dahlan Al Barry, Kamus Ilmiah Populer (Surabaya: ARKOLA: 2001), 775.

${ }_{5}^{5}$ Taufiq Hidayat, "Rekonstruksi Konsep Ijbar”, dalam De Jum Jumal Syariah Dan Hukum, ..., 11.

6 Husnul Haq, "Reformulasi Hak Ijbar Dalam Tantangan Isu Gender Kontemporer", dalam Jumal PALASTREN, Vol. VIII, No. 1, Juni 2015, 215-216.
} 
dan melayani kebutuhan seks suami, melainkan juga bergulat dalam kerja-kerja, sosial, politik, profesional, dan sebagainya. Inilah fakta-fakta sosial baru yang sangat berbeda dengan kondisi perempuan pada abad pertengahan. ${ }^{7}$

Oleh karena itu, konsep hak j̈bâr Imam Shâfî̀ perlu direkonstruksi dengan melihat: pertama, perbedaan waktu. Konsep hak j̈bâr Imam Shâfiî tersebut dirumuskan pada abad $\pm 2 \mathrm{H}$, sekarang adalah abad ke $14 \mathrm{H}$. Kedua, perbedaan tempat. Konsep hak j̈bâr Imam Shâfî̀ tersebut dirumuskan di Timur Tengah, lebih tepatnya adalah di Mesir. Sekarang, penulis berada di Negara Indonesia, secara otomatis tradisi yang muncul sangat berbeda. Ketiga, perbedaan fenomena sosial perempuan yang terjadi. Pada zaman Imam Shâfiî merumuskan hak äbâr, perempuan hanya bertempat di harem-harem, dan posisinya sangat rendah. Sekarang, posisi perempuan sudah merangkak lebih baik, terbukti dengan adanya pemimpin perempuan.

Penekanan pada teori maslabah juga tidak boleh di abaikan, sebab teori ini memiliki prinsip mengambil manfaat dan menolak kemadaratan dalam rangka memelihara tujuan-tujuan syara' yang ada lima, yaitu: memelihara agama, jiwa, akal, keturunan dan harta. Apabila perbuatan yang intinya menjaga kelima tersebut, maka dinamakan maslahah, hal ini sesuai dengan pendapatnya Imam Ghozali. ${ }^{8}$

Dari ketiga alasan tersebut, maka kemaslahatan yang akan dituju juga berbeda. Mungkin, sekarang standart kemaslahatan yang diberikan Imam Shâfî̀ sudah dianggap sebagai madarat. Maka penulis ingin mengakaji ulang dan menyusun kembali konsep hak j̈bâr Imam Shâfî̀ yang disesuaikan dengan waktu, tempat, kondisi sosial perempuan dan kemaslahatan pada masa sekarang.

\section{Hak Ijbâr Wali Nikah Perspektif Imam Shâfi'î}

Tipologi atau metode khas istinbat Imam Shâfirî didasarkan pada Al-Qư'an,

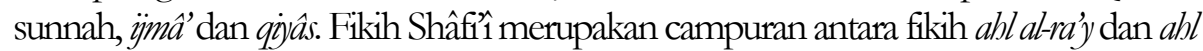
al-hadith. Perpaduan ini, ia bangun dalam usul alfigh yang dikenal dengan aliran mutakallimin (kalam).

Dengan keilmuan yang dimilikinya, Imam Shâfiî merumuskan hak j̈bâr wali nikah dengan sangat terperinci. Secara etimologi kata ̈̈bâr berasal dari ajbara-yujbinu-j̈bâran

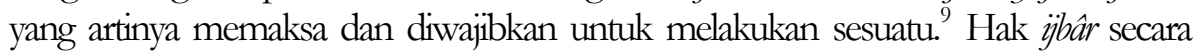
terminologi adalah hak ayah atau kakek untuk menikahkan anak perempuannya, baik yang sudah dewasa maupun masih berusia muda, tanpa harus mendapatkan persetujuan atau izin terlebih dahulu dari anak perempuan yang akan dinikahkan tersebut, asalkan ia bukan seorang janda. ${ }^{10}$ Berdasarkan ketentuan ini, para wali

\footnotetext{
${ }^{7}$ Marzuki Wahid, Figh Indonesia (Cirebon: ISIF, 2014), xxix.

${ }^{8}$ Abû Hamid al-Ghazâliy, al-Mushtasfâ fî Tlm al-Usûl (Beirut: Dâr al-Kutub al-Islâmiyyah, 1993), 286.

${ }^{9}$ Lous Ma'luf, al-Mumìnd Fî al-L ngot wa al-A'lam (Beirut: Dar al-Masyrik, 1968), 78.

10 'Abd al-Raḥman al-Jaziriy, al-Fïh 'alâ Madhâbib al-Arba'ah, ..., 24.
} 
memiliki hak untuk mengawinkan anak perempuannya yang masih di bawah umur, meski tanpa persetujuan yang bersangkutan. ${ }^{11}$

Perlu dikemukakan di sini bahwa dalam mazhab Shâfî̀ dikenal istilah ̈̈bâr bagi wali mujbir. Wali mujbir adalah orang tua calon mempelai perempuan, yang dalam aliran Shâfîi ialah ayah, atau kakek apabila ayahnya tidak ada. Walaupun demikian, hak j̈bâr ayah atau kakek tidak serta merta dapat dilaksanakan dengan sekehendak hatinya. Ulama' mazhab Shâfiî mengatakan bahwa untuk bisa mengawinkan anak laki-laki di bawah umur disyaratkan adanya kemaslahatan, sedang untuk anak perempuan diperlukan beberapa syarat, antara lain (1) Tidak adanya permusuhan yang nyata antara anak perempuan dengan walinya; (2) Tidak ada permusuhan yang nyata antara dia dengan calon suminya; (3) Calon suami harus sekufu'; (4) Calon suami harus memberikan maskawin yang pantas. ${ }^{12}$

Tentang masalah ỉbâr, Imam Shâfiî̀ menyandarkan pendapatnya pada sebuah hadis yang menceritakan perkawinan Rasul dengan 'Âishah putri Abû Bakr RA.:

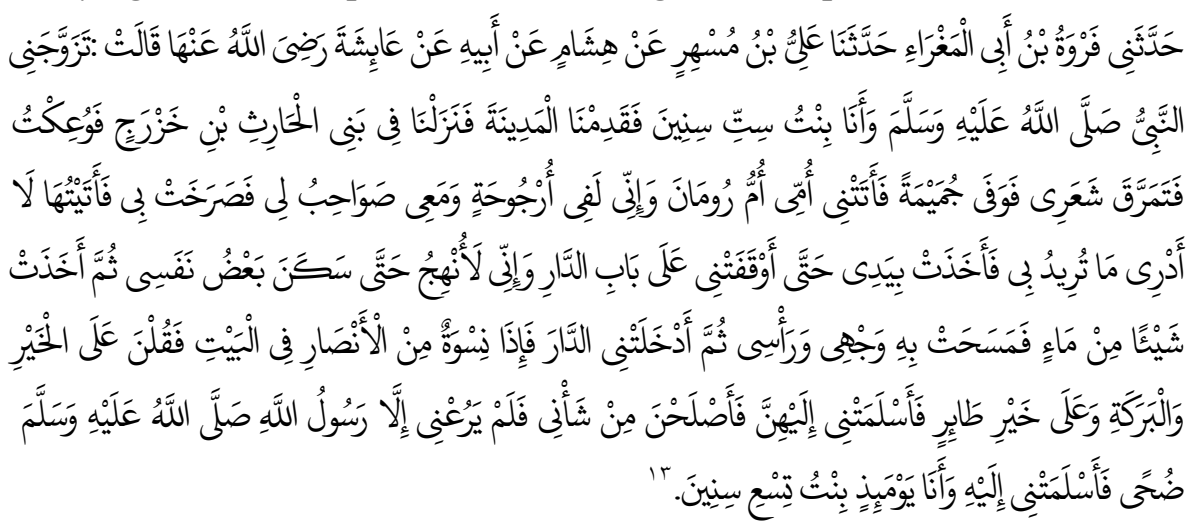

Artinya: Fanwah bin Abi al-Maghra' bererita kepadaku, 'Ali bin Mushir berrerita kepada kami, dari Hisham bin Unvah dari 'Aishah R A berkeata: "Nabi S AW menikabiku ketika aku masih berusia enam tahun. Kami berangkat ke Madinah. Kami tinggal di tempat Bani Haris bin Khajraj. Kemudian aku terserang pernyakit demam panas yang membuat rambutku banyak yang rontok. Kemudian ibuku, Ummu Ruman, datang ketika aku sedang bermain-main dengan beberapa orang temanku. Dia memangogilku, dan aku memenubi pangogilannya, sementara aku belum tabu apa maksudmya memangoilku. Dia menggandeng tanganku bingra sampai ke pintu sebuah rumah. Aku merasa bingung dan batiku berdebar-debar. Setelah perasaanku agak tenang, ibuku mengambil sedikit air, lalu menyeka muka dan kepalaku dengan air tersebut, kemudian ibuku membawaku masuk, ke dalam rumah itu. Ternyata di dalam rumah itu sudah

\footnotetext{
11 Wahbah al-Zuhayliy, al-Fiqh al-Islam wa Adillatuh, Vol. VII (Beirut: Dâr al-Fikr, 1997), 695.

12 Wahbah al-Zuhayliy, al-Figh al-Islam wa Adillatuh, ..., 695.

${ }^{13}$ Abû 'Abd Allah Muhammad bin Isma’il bin Ibrahim bin al-Mughirah bin Bardizabah, Shabih Bukhari, Vol. III (Beirut: Dâr al-Kitab al-Ilmiyah, t.th), 632.
} 
menunggu beberapa orang wanita Anshar. Mereka meryambutku seraya berkeata: 'Selamat, semoga kamu mendapat berkah dan keberuntungan besar.' Lalu ibuku menyerabkeanku kepada mereka. Mereka lantas merapikan dan mendandani diriku. Tidake ada yang membuatku kaget selain kedatangan Rasulullah SAW. Ibuku langsung menyerabkeanku kepada beliau, sedangkan aku ketika itu baru berusia sembilan tabun."(HR Bukhari).

Rasulullah SAW mengawini 'Âishah setelah Khâdijah, istri pertama Rasul, meninggal dunia, yakni tahun ke-3 (tiga) sebelum hijrah. ${ }^{14}$ Jika dikatakan dalam hadits bahwa 'Âishah berumah tangga dengan Rasul pada usia 9 tahun, berarti saat itu 'Âishah baru berada di kota Madinah pada tahun ke 3 Hijriyah. Al-Nawawi dalam menjelaskan hadits di atas mengemukakan bahwa tidak perlu izin bagi ayah untuk mengkawinkan anak perempuan yang masih kecil (belum mencapai usia dewasa atau baligh), sebab anak yang masih kecil tidak mungkin memberikan izin. Tentu pertimbangan yang digunakan oleh ayah adalah untuk kemaslahatan anak gadis yang dikawinkannya. ${ }^{15}$

Dalam hal penentuan usia baligh, patokannya adalah sampai seseorang dipandang cakap hukum. Dengan demikian jika terdapat seorang anak perempuan yang belum pernah mengeluarkan haid dan belum mencapai usia 15 (ima belas) tahun atas dirinya ${ }^{16}$ berlaku hak j̈bâr oleh walinya, sehingga wali boleh menikahkannya dengan lelaki siapapun tanpa harus meminta persetujuannya. Ketentuan ini berbeda halnya jika temyata anak perempuan yang akan dinikahkan telah mencapai usia bikr (gadis) ${ }^{17}$, maka bagi seorang wali dianjurkan untuk meminta izin jika ingin mengawinkannya, sekalipun hal ini tidak berupa kewaijban.

Dari titik ini Imam Shâfîi masih bersikukuh tentang adanya hak j̈bâr bagi seorang wali. Satu-satunya penyebab hilangnya hak j̈bâr seorang wali, hanyalah ketika perempuan berstatus sebagai janda. Kriteria janda menurut ketetapan Imam Shâfî̀ adalah karena telah berhubungan badan dengan laki-laki, baik melalui perkawinan yang sah ataupun jalan ilegal. Baik perempuan tersebut masih kecil ataupun sudah dewasa. ${ }^{18}$

Dari penjelasan di atas, seharusnya konsep hak j̈bâr wali nikah Imam Shâfî̀ mendapat dukungan masyarakat, terlebih bisa menjadi hukum adat. Sebab, rumusan yang dibuat oleh Imam Shâfî̀ sudah lengkap dari segala sisinya. Akan tetapi dalam

\footnotetext{
${ }_{14}$ Ahmad bin Hajar al-Asqalani, Fath al-Bari Syarh Shabih Muslim, Vol. IX (Beirut: Dâr Marifah, 1379 H.), 26.

15 Abû Zakariyâ Yahyâ bin Sharaf al-Nawâwiy, Sharḥ Sạậ̂ Muslim, Vol. IX (Beirut: Dâr Ihyâ‘ Turâth alArâbiy, 1392 H.), 206.

${ }^{16}$ Lihat selengkapnya di Abû Zakariyâ, Sharb! Sabî̉ Muslim, 17.

${ }^{17}$ Muslim bin Haij)ầ al-Naysâbûriy, Sabî̉ Muskim, Indeks 1421, ..., 604. Lihat juga analisis imam Syafỉi tentang biker (Muhammad bin Idrîs al-Shâfiìy, al-Umm, Vol. V, ... , 18.)

${ }^{18}$ Muhammad bin Idrîs al-Shâfiriy, al-Umm, Vol. V, ...,18.
} 
kenyataan sekarang rumusan tersebut mendapat banyak pertentangan dari beberapa aktifis gender. Dengan dalih kesetaraan gender-emansipasi wanita.

Pola pikir Imam Shâfiî adalah dengan model bayâniy. Secara sederhana dapat disebut sebagai paradigma teks, atau tekstualis, berawal dari teks, kembali ke teks, dan berpangku pada teks, yang terdiri atas teks bahasa Arab serta teks-teks agama (AlQur'an dan al-Hadis). Sebab, untuk memahami pesan-pesan agama, tentu dibutuhkan penguasaan yang baik terhadap bahasa Arab; dan kalau ingin berpikir, berperilaku, bertindak, dan menghayati agama secara sempurna maka harus merujuk pada teks-teks tersebut. ${ }^{19}$ Dengan pola pikir ini, maka penulis akan menganalisa pendapat Imam Shâfîi dari dalil terlebih dahulu. Kemudian ditarik kepada kenyataan yang ada.

\section{Analisis Dasar Hukum Imam Shâfi'î tentang Hak Ijbâr}

Rumusan Imam Shâfî̀ dilandaskan pada hadis perkawinan Rasul dengan 'Âishah putri Abû Bakr RA. di atas. Kualitas hadis tersebut adalah berkualitas daîf, penjelasannya adalah sebagai berikut:

Pertama, Penelitian Sanad. Dalam sanad hadis di atas terdapat 5 (ima) periwayat, yaitu: 1). Farwah bin Abî al-Maghra', 2). 'Alî bin Mushir, 3). Hishâm, 4). Abîhi (Urwah), 5). ‘Âishah RA.

1) Farwah bin Abî al-Maghra' (W. $225 \mathrm{H}$ )

Nama lengkap: Mu’dî Karbi al-Kindiy Abû al-Qâsim al-Kûfily. ${ }^{20}$

Guru-guru: Ibrâhin bin Mukhtar al-Râziy, Asad bin 'Amr al-Bajaliy al-Qadì, Zakariya bin 'Abd Allah bin Yazîd al-Sihbâniy, Abî al-Ahwaṣ Salâm bin Salìm, Shârik bin 'Abd Allâh, 'Abîdah bin Hamîid, 'Alî bin Mushir, al-Qasim bin Mâlik al-Muzniy, Muhammad bin Sulaiman bin al-Aṣbihâniy, al-Walîd bin Abî Thur, Yahya bin Zakariyâ bin Abî Zaidah. ${ }^{21}$

Murid-murid: al-Bukhâriy, Ibrahîm bin 'Abd Allah bin Janîd al-Khataliy, Abû alAzhar al-Naisâbûriy, Aḥmad bin 'Alî al-Kharrâz, 'Abbâs bin Muhammad alDûriy, 'Abd Allah bin 'Abd al-Rahman al-Dârimiy, 'Abd Allah bin Muhammad bin al-Nu'mân bin 'Abd al-Salâm al-Aṣbihâniy, Abû Zar'ah 'Ubaid Allah bin 'Abd al-Karîm al-Râziy, Uthmân bin Kharzậal-Antâqiy, al-Fadl bin Abî Ṭâlib alBaghdâdiy, Abû Hâtim Muhammad bin Idrîs al-Râziy, Muhammad bin Ishâq alȘaghâniy, Muhammad bin Ubaid bin Utbah al-Kindiy, Muhammad bin Uthmân al-Shaibah, Mû́sâ bin Sầd al-Dandâniy, Ya'qûb bin Sufyân al-Fârisiy. ${ }^{22}$

\footnotetext{
${ }^{19}$ Damanhuri, Ijtihad Hermeneutis (Yogyakarta: IRCiSoD, 2010), 15.

${ }^{20}$ Ibn Hajar al-Atsqalâniy, Tahdž̨̧ al- Tahdžlı, V. 8 (t.tp: Mauqi' Ya'sûb, t.th), 238.

${ }^{21}$ Yûsuf bin al-Zakiy 'Abd Allah Abû al-Hujjaj al-Muziy, Tahdž̨̧ al-Kamâl, V. 23 (Bairut: Muassisah al-Risâlah, 1980), 178.

${ }^{22}$ Yûsuf bin al-Zakiy ‘Abd Allah Abû al-Hujjaj al-Muziy, Tabdř̨̧ al-Kamâl, 178.
} 
2) 'Alî bin Mushir (W. 189 H)

Nama lengkap: 'Alî Bin Mushir bin 'Alî bin 'Amîr bin ‘Âṣim bin ‘Abîd bin Mushir al-Qurashiy al-Kûfiy.

Saudaranya: 'Abd al-Rahman bin Mushir.

Kunyabnya: Abû al-Hasan al-Kûfiy. ${ }^{23}$

Guru-guru: al-Ajlạ̣ bin 'Abd Allah al-Kindiy, Ismầil bin Abî Khâlid, Ismầil bin Muslim al-Makkiy, Ash'ath bin Suwâr, Abî Burdah Barîd bin 'Abd Allah bin Abî Burdah bin Abî Mûsâ al-Ash'ariy, Hamzah bin Habîb al-Ziyât, Dâwud bin Abî hindin, Zakariya bin Abî Zaidah, Sa'd bin Ṭarif al-Iskâf, Sa’id bin Abî Urûbah, Abî al-'Anbas bin Kathir bin 'Abîd al-Qurashiy, Sulaiman al-A'mash, Sâliḥ bin Hayyan al-Qurashiy, Ṭar̂f Abî Sufyân, 'Âṣim al-Ahwwal, 'Abd Allah bin 'Ạtâ', 'Abd alRaḥman bin Ishâq al-Kûfiy, 'Abd al-'Azîz bin 'Umar bin 'Abd al-'Azîz, 'Abd alMuluk bin Abî Sulaimân, 'Abd al-Muluk bin 'Abd al-'Azîz bin Jariji, Ubaid Allah bin Umar, Ubaidah bin Mu’tab al-Ḍabiy, Uthmân bin Ḥakîm al-Anșâriy, Iṣâm bin Qudâmah, Umar bin Dzar, al-Fạ̣l bin Yazîd al-Thimâliy, Muhammad bin Ubaid Allah al-Urzumiy, Muhammad bin Qays al-Asdiy, al-Mukhtar bin Falfal, Mutrraf bin Ṭariff, Mûsâ al-Juhniy, Hisham bin 'Urwah, Yạ̣ya bin Saî̀ alAnșâriy, Yazìd bin Abî Ziyâd, Abî Ishaq al-Shaibaniy, Abî Hayyan al-Taimiy, Abî Mâlik al-Ashja'iy.

Murid-murid: Ibrâhim bin Muhdiy al-Muṣ̣̣̂̂̂, Ismâîl bin Abân al-Warâq, Ismaîl bin al-Khalill, Ayûb bin Manșûr, Bishr bin Âdam al-Darîriy, al-Hasan bin Rabî alBurâniy, Khâlid bin Mukhlid al-Qạtwâniy, Zakariyâ bin 'Adiy, al-Sirrî bin Mughlis al-Siqtiy, Sahl bin Uthman al-Askariy, Suwaid bin Sa'id, 'Abd Allah bin 'Âmir bin Zarrârah, Abû Bakr 'Abd Allah bin Muhammad bin Abî Shaibah, 'Abd alGhaffâr bin 'Abd Allah bin al-Zubair al-Muṣiliy, Uthman Muhammad bin Abî Shaibah, 'Alî bin Hajar al-Sa'diy, 'Alî bin Hakîm al-Audiy, 'Alî bin Sa’id bin Masrûq al-Kindiy, Farwah bin Abî al-Maghra', Muhriz bin 'Aun, al-hilâliy, Muhammad bin Sâ̂̀d bin al-Aṣbihâniy, Muhammad bin Ubaid al-Mahâribiy, Muhammad bin Umar bin al-Rûmiy, Ma'lâ bin Mansûr al-Râziy, Munjâb bin al-Hậtîth al-Tamîmiy, Hunâd bin al-Sirriy al-Tamîmiy, Abû Humâm al-Walîd bin Shujầ al-Sukûniy, Yahya bin 'Abd al-Hamîd al-Hamâniy.

3) Hishâm (W.140 H)

Nama lengkap: Hishâm bin 'Urwah bin al-Zubair bin al-'Awâm al-Qurashiy alAsadiy Abû al-Mundzir, dan disebutkan Abû 'Abd Allah al-Madiniy.

Guru-guru: Bakr bin Wâil, Sâliḥ bin Rabîah bin al-Hudîr al-Taymiy, Sạlih bin Abî Sâlị̣ al-Samân, Tbâd bin Hạzzah bin 'Abd Allah bin Zubair, Tbâd bin 'Abd

${ }^{23}$ Muhammad bin Ḥibbân bin Aḥmad Abû Hatûm al-Tamîmiy al-Bustiy, al-Thiqât, V. 7 (Bairut: Dâr al-Fikr, 1975), 214. 
Allah bin al-Zubair, 'Abd Allah bin Abî Bakr bin Hazm, Abî al-Zanâd 'Abd Allah bin Dzakwân, Urwah bin al-Zubair, 'Abd Allah bin Zubair, 'Abd Allah bin 'Âmir bin Rabî’ah, 'Abd Allah bin 'Urwah bin Zubair, 'Abd al-Rahman bin Sa'd al-Madiniy, 'Abd al-Raḥman bin al-Qâsim bin Muḥammad bin Abî Bakr al-Sadî̀, 'Abd al-Raḥman bin Ka'b bin Mâlik bin Ubaid Allah bin 'Abd al-Raḥman, Uthmân bin 'Urwah bin al-Zubair, Umar bin 'Abd Allah bin 'Umar bin alKhațab, 'Amr bin Huzaimah, 'Amr bin Shu'aib, 'Auf bin al-Hârith bin al-Ṭfuail, Karî̉ Maulâ bin 'Abbâs, Muhammad bin Ibrâhim bin al-Hâarith al-Tìmiy, Muhammad bin 'Alî Bin 'Abd Allah bin 'Abbâs, Muhammad bin Muslim bin Shihab al-Zuhriy, Abî al-Zubair Muḥammad bin Muslim al-Makkiy, Muḥammad bin al-Munkadir, Wahb bin Kîsaniy, Yahyâa bin Ibâd bin 'Abd Allah bin al-Zubair, Yazîd bin Razîn Abî Salamah bin 'Abd al-Rạ̣man bin 'Auf, Abî Wajzah al-Su’diy, Fâtimah bint al-Mundzir bin al-Zubair.

Murid-murid: Abân bin Yazîd al-Ațâr, Ibrâhim bin Hamîd bin 'Abd al-Raḥman al-Ruâsiy, Abû Isḥaq Ibrâhim bin Muhammad al-Fazâriy, Usâmah bin Haf̣̣ alMadiniy, Istâil bin Yûnus, Ismâ’il bin 'Aliyah, Ismâil bin Tyâs, Abû Damrah Anas bin Tyâd, Ayyûb bin Wâqid al-Kûfiy, Ayyûb al-Sukhtiyâniy, Jarîr bin 'Abd alHamîd, Ja'far bin Sulaimân al-Ḍab’iy, Ja'far bin 'Aûn, Junâdah bin Salam, Hâtim bin Ismầil, al-Hârith bin Imrân al-Ja’fariy, Habîb al-Mu’allim, Haf̣̣ bin Ghiyâth, Haf̣̣ bin Maisarah, Abû Usâmah Hamâd bin Usâmah, Hạamâd bin Zayd, Hạamâd bin Salamah, Abû al-Aswad Hamîd bin al-Aswad, Hamd bin 'Abd alRaḥman al-Ruâsiy, Khâlid bin al-Hârith, Dâwud bin 'Abd al-Rahamn al-'Atâar, Dâwud bin Nașîr al-Ṭâiy, Raụ bin al-Qâsim, Zâidah bin Qudâmah, Zuhair bin Muhammad al-Anbariy, Zuhair bin Mu'âwiyah, Sâ̂̀d bin Abî Sầì al-Zubaidiy, Saîd bin Salamah bin Abî al-Hisâm, Saîd bin 'Abd al-Raḥman al-Jumhiy, Sufyân al-Thauriy, Sufyân bin 'Uyainah, Salamah bin Rajầ al-Tamîmiy, Sulaimân bin Bilâl, Abû Khâlid Sulaimân bin Hayyan al-Aḥmar, Salâm bin Abî Mự̂̀, Sharîk bin 'Abd Allah, Shu'bah bin al-Hujjaj, Shuaib bin Ishâq al-Dimashqiy, Shuaib bin Abî Hamzah, Sakhr bin Juwairiyah, al-Ḍahâa bin Uthmân al-Hazâmiy, 'Âmir bin Ṣâlị al-Zubairiy, Ibâd bin Tbâd al-Mahlibiy, Tbâd bin Manșûr, 'Abd Allah bin Idrîs, 'Abd Allah bin Dâwud al-Huraibiy, 'Abd Allah bin al-Mubârak, 'Abd Allah bin alMunîb al-Madiniy, 'Abd Allah bin Namîr, 'Abd al-Rạ̣man bin Abî Zanâd, 'Abd al-Rahîm bin Sulaimân, 'Abd al-'Azîz bin Abî Hâzzim, 'Abd al-'Azîz bin Abî Salamah al-Mâjishun, 'Abd al-'Azîz bin Muhammad al-Darâwardiy, 'Abd al-'Ażiz bin al-Mukhtâr, 'Abd al-Muluk bin Juraij, 'Ubadah bin Salaimân, 'Ubaid Allah bin 'Abd al-Rahman al-Ashjäiy, Ubaid Allah bin 'Umar al-Umariy, Ubaid Allah bin Mûsâ, 'Ubaid bin al-Qâsim al-Kûfiy, 'Athâm bin al-'Âmiriy, 'Uthmân bin Farqad, Uqbah bin Khâlid al-Sukûniy, 'Alî bin Mushir, 'Alî bin Hâshim bin al-Barî̀, 
Umar bin Habîb al-'Adwiy al-Qâdịy, 'Umar bin 'Alî al-Muqaddimiy, 'Umar bin Qays al-Makkiy Sandal, 'Amr bin al-Hârith al-Mișriy, 'Anbasah bin 'Abd al-Wâhid al-Qurashiy, T̂sâ bin Yûnus, al-Faḍl bin Mûsâ, Falyạ̣ bin Sulaimân, Qirân bin Tamâm al-Asadiy, al-Layth bin Sa'd, Mâlik bin Anas, Mâlik bin Su'aîr bin alKhamsi, Muhâạir bin al-Mûri', Muhammad bin Ishââ bin Yasâr, Muhammad bin Bishr al-'Abdiy, Muhammad bin Ja'far bin Abî Kathîr, Abû Mu’âwiyah Muḥammad bin Khâzim al-Ḍarîr, Muhammad bin Rabî̉ah al-Kilâbiy, Muhammad bin 'Abd Allah bin Kinânah, Muhammad bin 'Abd al-Raḥman bin Abî Dzi’b, Muhammad bin 'Abd al-Raḥman al-Ṭafâwiy, Muhammad bin 'Ajlân, Muḥammad bin Fuḍail al-Ḍabiy, Muhammad bin Muslim bin Abî al-WaḍâḥAbû Saî̀ al-Mu’addib, Muhammad bin al-Walî̀d al-Zubairiy, Muslim bin Khâlid alZanjiy, Muslimah bin Q'’nab al-Hârithiy, Mu’ammar bin Râshid, al-Mundzir bin 'Abd Allah, Wâlid Ibrâhim bin al-Mundzir al-Hazâmiy, Muhdî bin Maimûn, Najịh Abû Mìshar al-Madaniy, al-Naḍar bin Shamîl, Hishâm bin Hisân Hishâm bin Sulaimân al-Makhzûmiy, Hisham bin 'Abd Allah bin Tkrimah al-Makhzûmiy, Hammâm bin Yạ̣yâ, Waqû̉ bin Jarâh Wahîb bin Khalîd, Yahyya bin Zakariyâ bin Abî Zâidah, Yahya bin Abî Zakariyâ al-Ghisâniy, Yahya bin Sầid al-Anșâriy bin Saîd al-Amwî, Yahyya bin Saîd al-Qạttân, Yạyya bin 'Abd Allah bin Sâlim, Abû Zakîr Yahya bin Muhammad bin Qays al-Madiniy, Yahya bin Yamân, Yazîd bin Zurai', Ya'Qûb bin Walîd al-Madiniy, Ya'lâ bin Shabîb, Yûnus bin Bakîr alShaibaniy, Yûnus bin Yazîd al-Ailiy, Abû Bakr al- Mudîniy, Abû al-Mathnâ alKa'biy. ${ }^{24}$

4) Abihi (Urwah) (W.94 H)

Nama lengkap: Urwah bin al-Zubair bin al-'Awâm bin Khuwailid bin Asad bin 'Abd al-Izziy bin Qușay al-Qurashiy, al-Asadiy Abû 'Abd Allah al-Madiniy.

Guru-guru: Usâmah bin Zaid bin Hârithah al-Kalbiy, Bashîr bin Sa'd Bashîr bin Abî Mas'ûd al-Anșâriy, Jâbir bin 'Abd Allah, Jamhân Maulâ al-Aslamiyainiy, Hajjầi bin Hajijâj al-Aslamiy, al-Hasan wa al-Husain ibnai 'Alî bin Abî Ṭâlib, Hakîm bin Hạâm, Hamrân bin Abân, Ḥamzah bin 'Amr al-Aslamiy, al-Zubair bin 'Awâm, Zaid bin Thâbit, Zaid bin al-Salt, Sầ̂d bin Zaid bin 'Amr bin Nufail, Thufyân bin 'Abd Allah al-Thaqafiy, Sahl bin Abî Hithamah 'Âṣim bin Umar bin al-Khattâb, 'Abd Allah bin al-Arqam, 'Abd Allah bin Ja’far bin Abî Ṭâlib, 'Abd Allah bin alZubair, 'Abd Allah bin Zam'ah bin al-Aswad, 'Abd Allah bin 'Abbâs, 'Abd Allah bin 'Umar bin al-Khattâb, 'Abd Allah bin 'Amr bin al-Ậs, 'Abd al-Rahman bin 'Abd al-Qâri', 'Abd Allah bin 'Âdiy bin al-Khiyâr, Uthmân bin Ṭalhạh al-Hijabiy, 'Alî bin Abî Ṭâlib, 'Umar bin Abî Salamah, 'Amr bin al-'Âs,, Qays bin Sa’d bin

${ }^{24}$ Yûsuf bin al-Zakiy ‘Abd Allah Abû al-Hujjaj al-Muziy, Tahdž̨̧ al-Kamâl, V. 30 (Bairut: Muassisah al-Risâlah, 1980), 234237. 
Ubâdah, Muhammad bin Muslimah al-Anșâriy, Marwân bin al-Hakîm, al-Masûr bin al-Makhramah, Mu'âwiyah bin Abî Sufyân, al-Mughîrah bin Shu'bah, Nâjịh alAslamiy, Nâfi' bin Jabîr bin Mựim, al-Nu'mân bin Bashîr, Niyâr bin Mukram alAslamiy, Hishâm bin Hakîm bin Hazâm, Yahyya bin 'Abd al-Raḥman bin Khậtib, Abî Hamîd al-Sầidiy, Abî Sầid al-Khudriy, Abî Salamah bin 'Abd al-Rahman bin 'Auf, Abî Marâwị al-Ghaffâriy, Abî Hurairah, Asmâ' bin Abî Bakr al-Ṣadiq, Asmầ bin Umais, Busrah bint Șafwân, Zainab bint Abî Salamah, Ḍibâah bin alZubair bin 'Abd al-Mutâlib, 'Âishah, Imrah bint 'Abd al-Rahman, Fậtimah bint Abî Habîsh, Fâtimah bin Qays, Ummu Habîbah bint Abî Sufyân, Ummu Salamah, Ummu Shar̂̀k, Ummu Hanî̉ bin Abî Ṭâlib.

Murid-murid: Bikr bin Sawâdah al-Jadzamiy, Tamîm bin Salamah al-Salamiy, Ja'far bin Muhammad bin 'Alî bin al-Husain, Ja'far bin Musỉb, Habîb bin Abî Thâbit, Habîib mualâ 'Urwah bin al-Zubair, Khâlid bin Abî Imrân Dâwud bin Mudrik, al-Zabriqânî bin 'Amr bin Umayah al-Ḍamriy, Zamîl bin 'Abbâs, Sa'd bin Ibrâhim bin 'Abd al-Raḥman bin 'Auf, Saî̀d bin Khâlid bin 'Amr bin Uthmân bin 'Affầ, Sulaiman bin 'Abd Allah bin 'Umaimir al-Aslamiy, Sulaimân bin Yasâr, Shaibah al-Khaḍriy, Sâliḥ bin Hisân al-Anșâriy, Sâalị̣ bin Kîsân, Ṣafwân bin Salìm, 'Âṣim bin Umar bin Uthmân, 'Abd Allah bin Insân al-Ṭâifiy, 'Abd Allah bin Abî Bakr bin Muhammad bin 'Amr bin Hazm, Abû al-Zanâd 'Abd Allah bin Dzakwân, 'Abd Allah bin Abî Salamah al-Mâjishûn, 'Abd Allah bin 'Abd Allah bin Abî Malîkah, 'Abd Allah bin Urwah bin al-Zubair, 'Abd Allah bin Nayyâr bin Mukrim al-Aslamiy, 'Abd Allah al-Bahiy, 'Abd al-Rahman bin Hamîd bin 'Abd Rạ̣man bin 'Auf, Ubaid Allah bin 'Utbah bin Mas'ûd, Uthmân bin 'Urwah bin al-Zubair, Uthmân bin al-Walîd, Irâk bin Mâlik, 'Atầ bin Abî Rabâh, 'Alî bin Zaid bin Jad'ân, Imrân bin 'Abd Allah bin 'Urwah bin al-Zubair, 'Umar bin 'Abd al'Azî̀z, 'Amr bin Dînar, 'Imrân bin Abî Anas, Mujâhid bin Wardân, Muḥammad bin Ibrâhim bin al-Hârith al-Tîmiy, Muhammad bin Ja'far bin al-Zubair, Abû alAswâd Muhammad bin 'Abd al-Raḥman bin Naufal, Muhammad bin 'Urwah bin al-Zubair, Muhammad bin Muslim bin Shihâb al-Zuhriy, Muḥmmad bin alMunkadir, Makhlad bin Khaffâf al-Ghafâriy, Musâfi' bin Shaibah al-Habîbiy, Muslim bin Qart, Mu'âwiyah bin Ishâa bin Talhậh bin 'Abd Allah, al-Mundzir bin al-Mughîrah, Mûsâ bin 'Uqbah, Hishâm bin 'Urwah, Hilâl bin Abî Hamîd alWazân, al-Walîd bin Abî al-Walî̀, Wahb bin Kîsân, Yạ̣yâ bin 'Urwah bin alZubair, Yahyâ bin Abî Kathîr, Yazîd bin Rûmân, Yazîd bin 'Abd Allah bin Khașifah, Yazîd bin 'Abd Allah bin Qasît, Yazîd bin Abî Yazîd al-Mișriy, Abû Burdah bin Abî Mûsâ al-Ash'ariy, Abû Bakr bin Hafṣ bin 'Umar bin Sa’d bin Abî Waqâs, Abû Salamah bin 'Abd al-Raḥman bin 'Auf.

5) 'Âishah RA (W. 58 H) 
Nama lengkap: 'Âishah bint Abî Bakr al-Ṣadîq

Kumyahnya: 'Umm 'Abd Allah

Guru-guru: Meriwayatkan dari Rasulullah

Murid-murid: Ibrâhim bin Yazîd al-Tîmiy, Ibrâhim bin Yazîd al-Nakhầiy, Ishâaq bin Țalhah bin Ubaid Allah, Ishâaq bin 'Amr, al-Aswad bin Yazîd al-Nakhâiy, Aiman al-Makkiy, Thamâmah bin Hazm al-Qushairiy, Jabîr bin Nufair alHaḍramiy, Jamî' bin 'Amîr al-Taimiy, al-Harîth bin 'Abd Allah bin Abî Rabî̉ah alMakhzûmiy, al-Harîth bin Naufal bin 'Abd al-Mutallib, al-Hasan al-Bașriy, Hamzah bin 'Abd Allah bin 'Umar bin al-Khattâh, Khalîd bin Darik al-'Asqalâniy, Khâlid bin Sa'd, Khâlid bin Ma'dân al-Kilầiy, Khabbâb, Khabîb bin 'Abd Allah bin al-Zubair bin al-'Awâm, Khalâs bin 'Amr al-Hijriy, Abû Ziyâd Khiyâr bin Salamah al-Shâmiy, Khaithumah bin 'Abd al-Raḥman al-ju'fiy, Dzakwân Abû Șalị̣ al-Simân, Dzakwân Abû 'Amr, Rabîah bin 'Amr al- Jarashiy, Zâdzân Abû 'Amr al-Kindiy, Zarârah bin Aufa, Zur bin Habîs al-Asadiy, Zaid bin Aslam, Zaid bin Khâlid al-Juhniy, Sâlim bin Abî al-Ja'd al-Ghạtfâniy, Sâlim bin 'Abd Allah bin 'Umar, Sâlim Subulân Abû 'Abd Allah, Sâib bin Yazid, Sa'd bin Hishâm bin ‘Âmir al-Anșâriy, Saî̀ bin Jubair, Sâ̂̀d bin Abî Sầid al-Maqbariy, Sầd bin al-Âṣ, Sâ̂̀d bin Musayyab, Sulaiman bin Barîdah, Sulaiman bin Yasâr, Sawâ’ al-Khazầiy, Shuraikh bin Arta àh al-Nakhâiy, Shuraikh bin Hâni' al-Hârithiy, Sharîq al-Husniy, Abû Waîl Shaqîq bin Salamah al-Asadiy, Shahr bin Haushab, Șâlị̣ bin Rabîah bin al-Hudair al-Tîmiy, Șa’sa’ah bin Mu’âwiyah al-Tamimiy, Tawûs bin Kîsân alYamâniy, Ṭalhah bin 'Abd Allah bin 'Uthmân bin 'Ubaid Allah bin Ma'maf alYamaniy, 'Âbis bin Rabîah al-Nakhâiy, 'Âșim bin Hamîd al-Sukûniy, 'Âmir bin Sa'd bin Abî Waqậ, 'Amîr bin Sarâhil al-Shỉbiy, 'Tbâd bin Hamzah bin 'Abd Allah bin al-Zubair Tbâd bin 'Abd Allah bin al-Zubair 'Ubâdah bin al-Walî̀ bin Ubâdah bin al-Sâmit, 'Abd Allah bin Barîdah, Abû al-Walîd 'Abd Allah bin alHârith al-Bișriy, 'Abd Allah bin al-Zubair bin al-'Awâm, 'Abd Allah bin Abî Salamah al-Mâjishûn, 'Abd Allah bin Shaddâd bin al-Hâdiy al-Laithiy, 'Abd Allah bin Shaqị al-Aquiliy, 'Abd Allah bin Shihâb al-Khaulaniy, 'Abd Allah bin 'Âmir bin Rabî’ah, 'Abd Allah bin 'Abbâs, 'Abd Allah bin Ubaid Allah bin Abî malîkah 'Abd Allah bin Ubaid bin 'Umair al-Laithiy, 'Abd Allah bin 'Aqîm al-Juhniy, 'Abd Allah bin Umar bin al-Khạttâb, 'Abd Allah bin Farûh, 'Abd Allah bin Abî Qais alShâmiy, 'Abd Allah bin Muhammad bin 'Abî Bakr al-Sadîq, 'Abd Allah bin Abî 'Atîq Muhammad bin 'Abd Al-Raḥman bin Abî Bakr al-Ŝadiq, 'Abd Allah bin Wâqid bin 'Abd Allah bin 'Umar bin al-Khạttâb, 'Abd Allah bin Yazîd, 'Abd Allah al-Bahiy, 'Abd al-Raḥman bin al-Aswad bin Yazid al-Nakhâiy, 'Abd Raḥman bin al-Hârith bin Hishâm al-Makhzûmiy, 'abd al-Raḥman bin al-Rimâh, 'Abd Raḥman bin Saîd bin Wahb al-Hamdaniy, 'Abd al-Raḥman bin Shimâmah 
al-Mahriy, 'Abd Raḥman bin 'Abd Raḥman bin Sâbịtal-Jumhiy, 'Abd al-'Azîz bin Juraij al-Makkiy, 'Ubaid Allah bin 'Abd Allah bin 'Utbah bin Mas'ûd, Ubaid Allah bin Tyâd, 'Ubaid bin Abî al-Ju'd, 'Ubaid bin 'Amîr al-Laithiy, Trâk bin Mâlik alGhaffâriy, 'Urwah bin al-Zubair, Urwah bin al-Muzniy, 'Urwah bin 'Abd alRaḥman, 'Ațâ' bin Abî Rabâh, 'Ațâ' bin Yasâr, Ikrimah, 'Alqamah bin Qais alNakhâiy, 'Alqamah bin Waqậs al-Laithiy, 'Alî bin al-Husain bin 'Alî bin Abî Ṭâlib 'Amr bin Sầd bin al-'Âṣ al-Amwâ, Abû Maisarah 'Amr bin Shurhubail alHamdaniy, 'Amr bin al-'Âs, 'Amr bin Ghâlib al-Hamdâniy, 'Amr bin Maimûn alAdwiy, 'Imrân bin al-Hatṭân al-Sudûsiy, 'Auf bin al-Hârith bin al-Ṭufail, Tyậ̣̂ bin 'Urwah, T̂sâ bin Talhạh bin 'Ubaid Allah, Ghadịf al-Hârith, Farwah bin Naufal alAshjały, al-Qâsim bin Muhammad bin Abî Bakr al-Sâdiq, al-Qa'qầ' bin Hakîm, Qais bin Abî Hâzzim, Kathîr bin Shihâb al-Mudzhajiy, Abû Saî̀ Kathîr bin 'Ubaid al-Kûfiy, Karîb, Mâlik bin Abî 'Âmir al-Aṣbahị, Mujâhid bin Jabr al-Makkiy, Muhammad bin Ibrâhîm bin al-Hârith al-Taimiy, Muhammad bin al-Ash'ats bin Qais al-Kindiy, Muhammad bin Ziyâd al-Jumhiy, Muhammad bin Sîrîn, Muḥammad bin 'Abd al-Raḥman bin al-Hârith bin Hishâm Abû Ja'far Muḥammad bin 'Alî bin al-Husain, Muhammad bin Qais bin Mukhramah bin alMutallib, Muhammad bin al-Muntashir al-Hamdaniy, Muhammad bin alMunkadir al-Taimiy, Marwân Abû Lubâbah al-'Aquiliy al-Bașriy, Masrûq bin alAjda', Mașda' Abû Yahyâ al-Ma'raqab, Mutraf bin 'Abd Allah bin al-Shakhîr, alMutallib bin 'Abd Allah bin Khantab al-Makhzûmiy, Muqsim, Makhû al-Shâmiy, Mûsâ bin Ṭalhạh bin 'Ubaid Allah Maimûn bin Abî Shabîb bin Muhrân, Nâfi' bin Jâbir bin Mựim, Nâfi' bin 'Atâa', Nâfi', al-Nu’mân bin Bashîr al-Anșâriy, Hammâm bin al-Hârith al-Nakhâiy, Hilâl bin Yasâf, Yahyya bin al-Jazâr, Yahya bin Saî̀ bin al-Âṣ al-Amwiy, Yạ̣ya bin 'Abd al-Raḥman bin Hậtib, Yahyâ bin Ya'mar, Yazîd bin Bâbinûs, Yazîd bin 'Abd Allah bin al-Shakhîr, Ya'lâ bin 'Uqbah, Yûsuf bin Mâhik, Abû Umâmah bin Sahl bin Haninf, Abû Burdah bin Abî Mûsâ al-Asy'ariy, Abû Bakr bin 'Abd al-Rahaman bin al-Hârith bin Hishâm, Abû alJauzầ al-Rabî̀iy, Abû Hudzaifah al-Arhabiy, Abû Ḥafșah, Abû al-Huwairith, Abû Zubair al-Makkiy, Abû Salamah bin 'Abd al-Rahman bin 'Auf, Abû al-Ash'ithâ' alMahâribiy, Abû al-Sâdiq al-Nâijy, Abû Dzobyân al-Janabiy, Abû al-'Âliyah alRiyâhiy, Abû 'Abd Allah al-Jadaliy, Abû Ubaid Allah bin 'Abd Allah bin Mas'ûd, Abû 'Utbah bin 'Alî, Abû Uthmân al-Nahdiy, Abû 'Udzrah, Abû 'Atịyah alWâdỉiy, Abû Qilâbah al-Jarâmiy, Abû al-Mutawakkil al-Nâniy, Abû Malị̂ alHadzaliy, Abû Mûsâ al-Ash'ariy, Abû Naufal bin Abî 'Aqrab, Abû Hurairah alDûsiy, Abû Yunûs, Asmâ' bin 'Abd al-Rahmman bin Abî Bakr al-Sâdiq, Umayah bint 'Abd Allah, Banânah bint Yazîd al-'Abashamiyah, Banânah, Bahiyah, Jasrah bin Dajâjah, Jamîlah bin Tbâd, Hạf̣̣ah bin 'Abd al-Rahmman bin Abî Bakr al-Ṣâdiq, 
Khairah, Daqrah bint Ghâlib, Rumaithah, Zainab bin Naṣr, Zainab al-Sahmiyah, Sâibah, Sumayah al-Bașiyah, Sumayah al-'Atkiyah, Safiyyah bin al-Hârith, Safiyyah bin Shaibah, Șafiyyah bin Abî 'Ubaid, Șafiyyah bin 'Tșmiyyah, al-Ṣamâ' bin Bisr, 'Âishah bint Ṭalhah bin 'Abd Allah, Imrah bint 'Abd al-Rahman, Imrah, Qarṣâfah, Qumair, Karîmah bint al-Humâm, Kulthum, Marjânah, Musikah alMakiyyah, Mu'âdzah al-'Adâwiyah, Hindun bint Sharîk bin Zubân al-Bașriyyah Umm Abî Bakr, Umm Jụ̣dar al-Ấmiriyyah, Umm Ḥamîdah bint 'Abd alRaḥman, Umm Dzurrah al-Madiniyyah, Umm Sâlim bint Mâlik al-Râsibiyyah, Umm 'Alqamah, Umm Kulthûm bint Abî Bakr al-Sadîq, Umm Kulthûm bint Thumâmah, Umm Kulthûm bint al-Laithiyyah, Umm Kulthûm, Umm Muhammad (istri Zaid bin 'Abd Allah). ${ }^{25}$

Kedua, Menguji Ke-thiqah-an Para Periwayat: (1) Farwah bin Abî al-Maghra' (W.

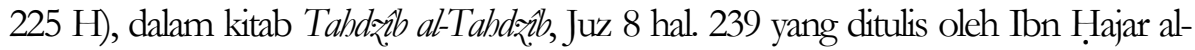
Athqalâniy, Abû Hâtim mengatakan: صنوق, al-Dâr al-Qutniy: menthiqẩkannya, Ibn Hibbân memasukkannya dalam kitab thiqâtnya. ${ }^{26}$ Sedangkan dalam kitab Tabdð̨̧̨ alKamâl, Juz 23 hal. 178 yang ditulis oleh Yûsuf bin al-Zakiy 'Abd Allah Abû al-Hujjaj al-Muziy, Abû Hatim mengatakan: صدوق.27 (2) 'Ali bin Mushir (W. 189 H), dalam kitab Tahdž̉ al-Kamâl, Juz 21 hal. 138 yang ditulis oleh Yûsuf bin al-Zakiy 'Abd Allah Abû al-Hujjaj al-Muziy, Aḥmad bin 'Abd Allah al-Ajaliy mengatakan: ثقنة, Abû Zar'ah: صنوق ثقة Sedangkan dalam kitab Ma'rifah al-Thiqât, Juz 2 Hal. 158 yang ditulis oleh Ahmad bin 'Abd Allah bin Sâlih Abû al-Hasan al-Ajaliy al-Kûfiy, disebutkan bahwasanya 'Ali bin

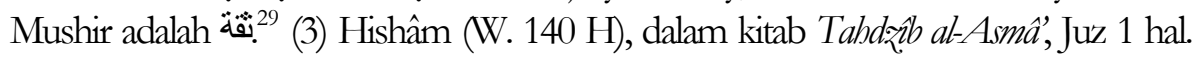
688 yang ditulis oleh Abî Zakariyâ Muhyî al-Dîn bin Sharaf al-Nawawiy, Ulama sepakat dengan kethiqahannya, keagungannya, kepemimpinannya. Muhammad bin

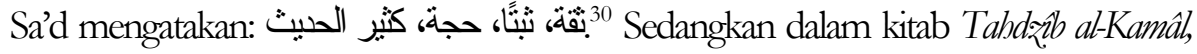
Juz 30 hal. 238 yang ditulis oleh Yûsuf bin al-Zakiy 'Abd Allah Abû al-Hujjaj al-Muziy,

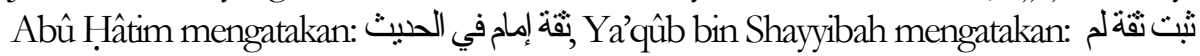

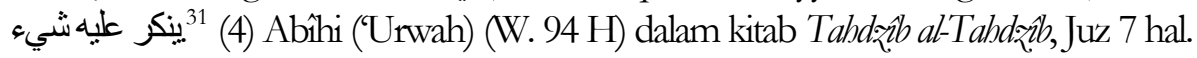

\footnotetext{
${ }^{25}$ Yûsuf bin al-Zakiy 'Abd Allah Abû al-Hujijaj al-Muziy, Tahdẓ̌̂’ al-Kamâl, V. 23 (Bairut: Muassisah al-Risâlah, 1980), 227-233.

${ }^{26}$ Ibn Hajar al-Athqalâniy, Tahdž̨̧ al-Tahdž̨̧, V. 8 (t.tp: Mauqi' Ya’sûb, t.th), 238.

${ }^{27}$ Yûsuf bin al-Zakiy 'Abd Allah Abû al-Hujjaj al-Muziy, Tahdž̨̧ al-Kamâl, V. 23 (Bairut: Muassisah al-Risâlah, 1980), 178.

28 Yûsuf bin al-Zakiy ‘Abd Allah Abû al-Hujjaj al-Muziy, Tabdz̨̨̧ al-Kamâl, V. 21, 138.

${ }^{29}$ Aḥmad bin 'Abd Allah bin Șâlih Abû al-Hasan al-Ajaliy al-Kûfiy, Márifah al-Thiqât, Vol. 2 (Madînah: Maktabah al-Dâr), 158.

${ }^{30}$ Abî Zakariyâ Muhyî al-Dîn bin Sharaf al-Nawawiy, Tabdž̨̧ al-Asmâ, Vol. I (t.tp: t.p, t.th), 688.

${ }^{31}$ Yûsuf bin al-Zakiy 'Abd Allah Abû al-Hujjaj al-Muziy, Tahdž̨̧ al-Kamâl, V. 30, 238.
} 


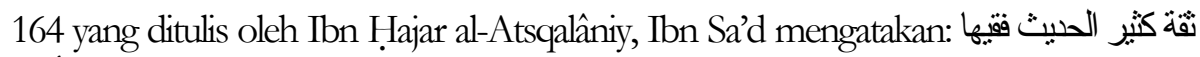

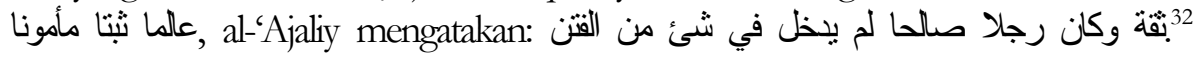
Sedangkan dalam kitab Tabdz̨̋ al-Kamâl, Juz 20 hal. 15 yang ditulis oleh Yûsuf bin alZakiy 'Abd Allah Abû al-Hujjaj al-Muziy, Muhammad bin Sa'd mengatakan ققة كثبر تقة وكان رجلا :Ahmad bin 'Abd Allah mengatakan al-'Ajaliy: الحيث فقيها عالما ملمونا ثبتا (4) 'Âishah bint Abû Bakr RA (W. 58 H) dalam kitab Tahdž̨ al-Kamâl, Juz 35 hal. 233 dan 235 yang ditulis oleh Yûsuf bin al-Zakiy 'Abd Allah Abû al-Hujjaj al-Muziy, Abû burdah bin Abî Mûsâ al-'Ash'ariy dari ayahnya

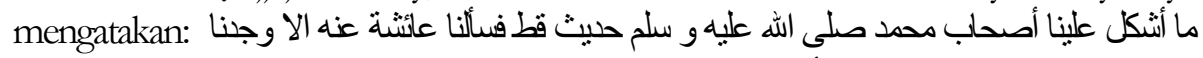

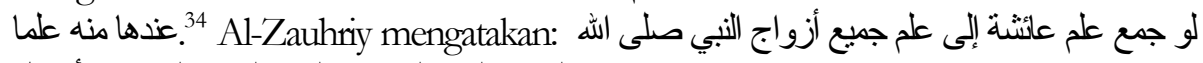

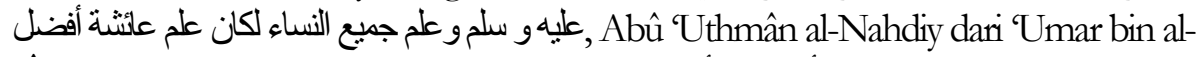

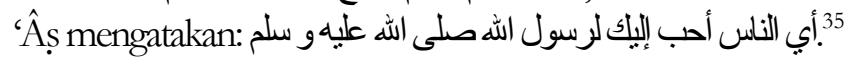

Ketiga, Menguji persambungan sanad. Penyajian dan analisis data persambungan sanad dapat disebutkan sebagai berikut:

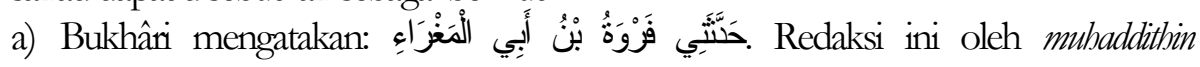
digunakan dalam periwayatan hadis dalam bentuk simâ,' yaitu pembacaan hadis oleh guru kepada murid. Dengan demikian berarti ada pertemuan antara Bukhâri dengan gurunya, yaitu: Farwah bin Abî al-Maghra', sanadnya muttasil.

b) Farwah bin Abî al-Maghra' mengatakan: حَنَّنَا عَلِيُ بْنُ مُسنْهِ Redaksi ini oleh mubadditbin digunakan dalam periwayatan hadis dalam bentuk simâ, yaitu pembacaan hadis oleh guru kepada murid. Dengan demikian berarti ada pertemuan antara Farwah bin Abî al-Maghra' dengan gurunya, yaitu: 'Alî bin Mushir, sanadnya muttasil.

c) 'Alî bin Mushir mengatakan: عَنْ هِ Pِكَاِ Periwayat 'Alî bin Mushir ini menggunakan redaksi 'an (ََ), tetapi 'an'anahnya tidak ada indikasi menunjukkan adanya keterputusan sanad, bahkan dapat dinyatakan bahwa sanadnya muttasil, karena: a) 'Alî bin Mushir adalah periwayat yang thiqah, b) dia bukan periwayat mudallis, dan c) dimungkinkan ada atau pernah bertemu antara 'Alî bin Mushir dengan gurunya: Hishâm. Dalam biografinya 'Alî bin Mushir disebutkan Hishâm adalah gurunya. Dalam biografinya Hishâm disebutkan 'Alî bin Mushir adalah muridnya.

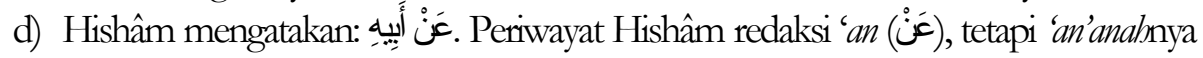
tidak ada indikasi menunjukkan adanya keterputusan sanad, bahkan dapat dinyatakan bahwa sanadnya muttasil, karena: a) Hishâm adalah periwayat yang thigah, b) dia bukan periwayat mudallis, dan c) dimungkinkan ada atau pernah bertemu antara Hisham dengan guru atau ayahnya: Abîhi (Urwah). Dalam

\footnotetext{
${ }^{32}$ Ibn Hajar al-Atsqalâniy, Tahdž̨ al-Tabdžlb, V. 8, 164.

33 Yûsuf bin al-Zakiy 'Abd Allah Abû al-Hujjaj al-Muziy, Tabdz̨̨̧ al-Kamâl, V. 20, 15.

${ }^{34}$ Yûsuf bin al-Zakiy 'Abd Allah Abû al-Hujjaj al-Muziy, Tabdrį̧ al-Kamâl, V. 35, 223.

35 Yûsuf bin al-Zakiy 'Abd Allah Abû al-Huijaj al-Muziy, Tabdrį̧ al-Kamâl, V. 35, 235.
} 
biografinya Hishâm disebutkan Abîhi ('Urwah) adalah gurunya. Dalam biografinya Abîhi ('Urwah) disebutkan Hishâm adalah muridnya.

e) Abîhi ('Urwah) mengatakan عَنْ عَاِثَنَ. Periwayat Hisham redaksi 'an (عَ), tetapi 'an'anahnya tidak ada indikasi menunjukkan adanya keterputusan sanad, bahkan dapat dinyatakan bahwa sanadnya muttasil, karena: a) Abîhi (Urwah) adalah periwayat yang thiqah, b) dia bukan periwayat mudallis, dan c) dimungkinkan ada atau pernah bertemu antara Abîhi ('Urwah) dengan guru atau ayahnya: 'Âishah. Dalam biografinya Abîhi ('Urwah) disebutkan 'Âishah adalah gurunya. Dalam biografinya 'Âishah disebutkan Abîhi (Urwah) adalah muridnya.

Keempat, Penyimpulan uji sanad. Setelah disajikan, dianalisa data-data yang berhubungan dengan kethiqaban para periwayat yang ada dalam sanad hadis yang diteliti, dan data-data persambungan sanadnya, maka disimpulkan sebagai berikut; (a) semua periwayat dalam sanad hadis tersebut, seluruhnya berkualitas thiqah; dan (b) semua periwayat masing-masing bertemu dengan periwayat yang berstatus sebagai gurunya, dengan demikian sanadnya muttasil. Dengan demikian dapat disimpulkan bahwa hadis yang diteliti sanadnya berkualitas sabîh al-isnâd.

Kelima, Penelitian matan. Secara kronologis, penulis perlu mencatat beberapa tanggal penting dalam sejarah Islam yang dimulai sejak masa Jahiliyah (pra Islamic era), yaitu sebelum wahyu turun sekitar Pra-610 M. Selanjutnya pada $610 \mathrm{M}$, turun wahyu pertama dan Abû Bakar menerima Islam. Selang tiga tahun kemudian, pada $613 \mathrm{M}$, Nabi Muhammad mulai mengajarkan Islam ke Masyarakat di Makkah dan pada 615 M, Nabi Muhammad Hijrah ke Abyssinia dan satu tahun kemudian yaitu pada 616 M, Umar bin Khattab baru masuk Islam. Pada 620 M, dikatakan Nabi meminang 'Âishah, dan dua tahun kemudian yaitu pada 622 M, Nabi Muhammad Hijrah ke Yathrib, yang kemudian dinamai Madinah. Dan pada 623/624 M, dikatakan Nabi SAW baru berumah tangga dengan 'Âishah. ${ }^{36}$

Tanggal-tanggal penting di atas selanjutnya akan dijadikan pijakan untuk mengkritisi atau meluruskan usia pemikahan 'Âishah dengan Rasulullah SAW. Karena dengan mengetahui latar kronologis di atas, setidaknya akan membantu melihat peristiwa demi peristiwa secara akurat dan tepat. Bagi penulis, ini menjadi hal yang urgen. Karena sebuah peristiwa pasti terkait dengan peristiwa lainnya/ berikutnya. Selain itu, kesimpangsiuran informasi atau sumber yang ada terkadang bisa menyebabkan kerancauan atau bahkan hasil yang diskriminatif.

Pertama, Menguji shâd dan tidaknya matan hadis. Tidak ada ayat yang secara eksplisit mengijinkan pernikahan seperti itu. Ada sebuah ayat, yang menuntun muslim dalam mendidik dan memperlakukan anak yatim. Petunjuk Al-Qur'an mengenai perlakuan anak Yatim juga valid diaplikasikan pada anak kita sendiri.

36 Wahyuni Shifatur R., Mengkeritisi Hadis-Hadis Tentang Usia Pernikahan Aisyah-Musawa Jurnal Studi Gender dan Islam, Vol. 8, No. 2, Juli 2009 (Yogyakarta: UIN Sunan Kali Jaga, 2009), 171. 


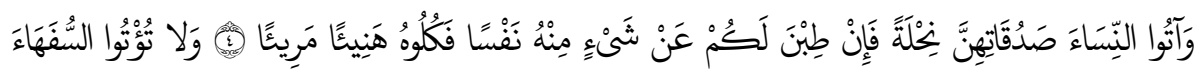

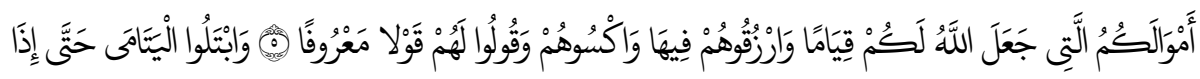

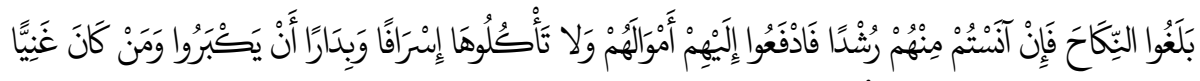

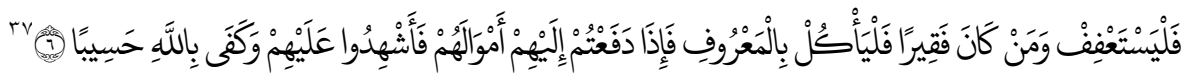

Artinya: Berikanlah maskawin (mahar) kepada wanita (yang kamu nikahi) sebagai pemberian dengan penub kerelaan. Kemudian jikea mereka menyerabkan kepada kamu sebagian dari maskawin itu dengan senang hati, Maka makanlah (ambillah) pemberian itu (sebagai makanan) yang sedap lagi baik akibatnya. Dan janganlah kamu serabkan kepada orang-orang yang belum sempurna akealnya, harta (mereka yang ada dalam kekenasaanmu) yang dijadikean Allah sebagai pokok kehidupan. Berilah mereka belanja dan pakeaian (dari hasil harta itu) dan ucapkanlah kepada mereka kata-kata yang baik. Dan ij̈lah anak yatim itu sampai mereka cukup umur untuk. kawin. Kemudian j̈ka menurut pendapatmu mereka telah cerdas (pandai memelihara barta), maka serabkanlah kepada mereka barta-hartanya. Dan janganlah kamu Makan harta anak yatim lebih dari batas kepatutan dan (janganlah kamu) tergesa-gesa (membelanjakannya) sebelum mereka dewasa. Barang siapa (di antara pemelihara itu) mampu, Maka hendaklah ia menahan diri (dari memakean harta anak yatim itu) dan barangsiapa yang miskin, maka boleblab ia Makan harta itu menurut yang patut. kemudian apabila kamu menyerabken harta kepada mereka, Maka hendaklah kamu adakan sakesi-saksi (tentang penyerahan itu) bagi mereka. Dan cukuplab Allah sebagai Pengawas (atas persaksian itu).

Dalam ayat di atas yang dimaksud dengan orang yang belum sempurna akalnya adalah anak yatim yang belum baligh atau orang dewasa yang tidak dapat mengatur harta bendanya.

Dalam hal seorang anak yang ditinggal orang tuanya, seorang muslim diperintahkan untuk (a) memberi makan, (b) memberi pakaian, (c) mendidik, dan (d) menguji terhadap kedewasaan "sampai usia menikah" sebelum mempercayakan mereka dalam pengelolaan keuangan.

Di sini, ayat Al-Qur'an menyatakan tentang butuhnya bukti yang teliti terhadap tingkat kedewasaan intelektual dan fisik melalui hasil test yang objektif sebelum memasuki usia nikah dan untuk mempercayakan pengelolaan harta-harta kepada mereka.

Dalam ayat yang sangat jelas di atas, tidak ada seorangpun dari muslim yang bertanggungjawab akan melakukan pengalihan pengelolaan keuangan pada seorang gadis berusia 7 tahun. Dengan kata lain, jika kita tidak bisa mempercayai gadis berusia 7 tahun dalam pengelolaan keuangan, berarti gadis tersebut sudah tidak memenuhi

${ }^{37}$ Q.S. Al-Nisa (4): 5-6. 
syarat secara intelektual maupun fisik untuk dinikahi. Ibn Hambal menyatakan bahwa 'Âishah yang berusia 9 tahun lebih tertarik untuk bermain dengan mainannya dari pada mengambil tugas sebagai isteri. ${ }^{38}$

Oleh karena itu sangatlah sulit untuk mempercayai, bahwa Abû Bakar, seorang tokoh muslim, akan menunangkan anaknya yang masih belia berusia 7 tahun dengan Nabi yang berusia 50 tahun. Sama sulitnya untuk membayangkan bahwa Nabi menikahi seorang gadis berusia 7 tahun.

Ayat di atas juga menunjukkan tugas penting lainnya dalam menjaga anak, yaitu mendidiknya. Mendidik anak bukanlah hal yang mudah, karena itu tidak mungkin (untuk tidak mengatakan mustahil) kita bisa mencapai hasil yang memuaskan sebelum mereka mencapai usia 7 atau 9 tahun, apalagi untuk siap menikah. Logika ini tentu akan memunculkan pertanyaan 'Bagaimana mungkin kita percaya bahwa 'Âishah telah dididik secara sempurna pada usia 7 tahun seperti diklaim sebagai usia pernikahannya, sebagaimana hadis yang diriwayatkan Hisyâm bin Urwah di atas?”

Abû Bakar merupakan seorang yang jauh lebih bijaksana dari kita semua, jadi dia akan merasa dalam hatinya bahwa 'Âishah masih seorang anak-anak yang belum secara sempurna sebagaimana dinyatakan Al-Qur'an. Abû Bakar tidak akan menikahkan 'Âishah kepada seorangpun. Begitu pula dengan Nabi SAW, jika beliau diminta untuk menikahi gadis belia dan belum terdidik secara memuaskan, tentu beliau akan menolak dengan tegas karena itu menentang hukum-hukum Al-Qur'an.

Kedua, Menguji mu'allal (cacat) dan tidaknya matan hadis. Terdapat dua analisa yang dapat digunakan; analisa eksternal dan internal.

Analisa Pertama; Eksternal. Setelah dilakukan penelitian, hadis-hadis yang menceritakan tentang usia perkawinan 'Âishah, baik yang menyatakan usia 9 tahun kemudian berkumpul dengan Nabi pada usia 12 tahun, atau sebagian riwayat lain yang menyebutkan dipinang usia 6 tahun dan dinikahi usia 9 tahun, temyata semuanya bermuara pada riwayat Hishâm ibn 'Urwah saja, ${ }^{39}$ yang mencatat atas otoritas dari bapaknya. Artinya, tidak ada isnad (periwayat) lain yang meriwayatkan hadis serupa. Adalah aneh bahwa tidak ada seorang pun di Madinah yang meriwayatkan hadis tersebut, dimana Hishâm ibn Urwah tinggal sampai usia 71 tahun baru menceritakan hal ini, di samping kenyataan adanya banyak murid-murid di Madinah termasuk yang kesohor Malik ibn Anas, tidak menceritakan hal ini. Pada akhimya diketahui bahwa riwayat ini berasal dari orang-orang Iraq, di mana Hishâm tinggal di sana setelah pindah dari Madinah pada usia cukup tua.

\footnotetext{
38 Aḥmad ibn Muhammad ibn Ḥanbal Al-Syaibânî, Musnad Aḅmad ibn Hanbal (Beirut: Dâr al-Ihyâ’ al-Turâs al-'Arabî, t.th.), 33 dan 99.

${ }^{39}$ Muslim Ibn Hạjjaj al-Qusyairî al-Nîsabûn̂, Sabîh Mushim (Mesir: al-Mạtba’ah al-Mișriyah, 1349 H), 141.
} 
Menurut catatan Ya'qûb bin Shaibah, "Hishâm sangat bisa dipercaya dan riwayatnya dapat diterima, kecuali apa-apa yang dia ceritakan setelah pindah ke Iraq". 40

Lebih lanjut Ya'qûb berkata bahwa Mâlik ibn Anas menolak riwayat Hishâm yang dicatat dari orang-orang Iraq: "Saya pernah diberi tahu bahwa Mâlik menolak riwayat Hishâm yang dicatat dari orang-orang Iraq." Keterangan lain juga diperoleh dari Mizân al-Itidâl, bahwa: "Ketika masa tua, ingatan Hishâm mengalami kemunduran yang mencolok". ${ }^{41}$

Dengan demikian, berdasarkan beberapa keterangan tersebut menginformasikan bahwa Ingatan Hishâm sangatlah buruk dan riwayatnya setelah pindah ke Iraq tidak bisa dipercaya, sehingga riwayatnya mengenai umur pernikahan 'Âishah adalah tidak kredibel.

Menurut penulis, hadis-hadis tersebut hanya bersifat informatif khabar insha', bukan khabar thalabi, yang menuntut untuk ditiru. Sekalipun hadis-hadis tersebut tercatat dalam Sahị̣̂ Bukhâriy, Sahịḥ Muslim, yang sudah terjamin kesahihannya, akan tetapi bagi penulis, jika hadis tersebut berdampak diskriminatif bagi perempuan atau isteri, maka kesahihan sanad tidaklah menjamin kesahihan matan. Oleh karena itu diperlukan penelitian mendalam melalui indikator (qarinah) pada matan hadis tersebut.

Analisa keduc, Internal. Dalam uji materi (kritik internal) ini, penulis melihat melalui beberapa aspek: aspek pertama, Bahasa. Di dalam hadis tentang pemikahan dini 'Âishah RA redaksi (matan) hadisnya menggunakan kalimat wa bija bintu situ sinina Kalimat bintu situ simina memang berarti anak perempuan berusia enam tahun, tapi jika dikaitkan dengan beberapa riwayat lain yang terkait, penulis menemukan ada beberapa kejanggalan.

Di antara riwayat yang mengindikasikan usia pemikahan 'Âishah bukan pada usia enam tahun adalah: Riwayat Ahmad ibn Hanbal, bahwa sesudah meninggalnya isteri pertama Rasulullah, Khadijah, Khaulah datang kepada Nabi dan menasehati Nabi untuk menikah lagi, Nabi bertanya kepadanya tentang pilihan yang ada di pikiran Khaulah. Khaulah berkata: "Anda dapat menikahi seorang gadis (bikr) atau seorang wanita yang pemah menikah (thayyib)". Ketika Nabi bertanya tentang identitas gadis tersebut (bikr), Khaulah menyebutkan nama 'Âishah.

Dalam leksikal bahasa Arab, kata biker tidak digunakan untuk gadis belia berusia 6 atau 9 tahun. Karena kata yang merujuk pada usia 6 atau 9 tahun adalah jarijah, yakni seorang gadis belia yang masih suka bermain-main. Sedangkan bikr pada umumnya digunakan untuk seorang wanita yang belum menikah serta belum punya pertautan pengalaman dengan pernikahan, sebagaimana kata yang dapat dipahami dalam

\footnotetext{
${ }^{40}$ Hisham bin Urwah adalah guru Imam Malik yang tinggal di Madinah sampai usia 71 tahun, kemudian pindah ke Iraq. Setelah pindah ke Iraq inilah, ingatannya menjadi berkurang, sehingga banyak ulama yang meragukan riwayatnya ketika ia berada di Iraq.

${ }^{41}$ Husein al-Zahabi, Mižan al-I'tidal (Pakistan: al-Maktabah al-Athriyyah, t.t.), 301.
} 
bahasa Inggris "virgin". Oleh karena itu, tampak jelas bahwa "bikr" bukanlah gadis belia yang baru berusia 6 atau 9 tahun. ${ }^{42}$

Dengan demikian, arti literal dari kata, bikr (gadis), dalam hadis di atas adalah "wanita dewasa yang belum punya pengalaman sexual dalam pernikahan." Oleh karena itu, 'Âishah adalah seorang wanita dewasa yang sudah pada waktunya untuk menikah.

Aspek kedua, Sejarah. Dalam konteks historis terdapat beberapa riwayat yang saling kontradiktif mengenai usia 'Âishah ketika dinikahi oleh Rasulullah SAW, di antaranya:

a) 'Âishah dipinang Nabi SAW

Menurut Tabari, juga menurut Hishâm ibn 'Urwah, Ibn Hạnbal dan Ibn Sa’ad, 'Âishah dipinang pada usia 7 tahun dan mulai berumah tangga pada usia 9 tahun. Tetapi, pada riwayat lain, menurut al-Thabari semua anak Abu Bakar (4 orang), termasuk 'Âishah, dilahirkan pada masa jahiliyah melalui 2 istrinya, atau sebelum Muhammad diutus menjadi Rasul. Ini berarti ketika Nabi hijrah ke Madinah, 'Âishah sudah berumur 13-14 tahun. Ini juga mengindikasikan ketika Rasulullah menikahi 'Âishah setahun setelah Hijrah, umur 'Âishah diperkirakan 1415 tahun. $^{43}$

Jika 'Âishah dipinang pada 620 M ('Âishah umur 7 tahun) dan berumah tangga tahun 623/624 M (usia 9 tahun), ini mengindikasikan bahwa 'Âishah dilahirkan pada 613 M. Sehingga berdasarkan tulisan al-Ṭabari, “Âishah seharusnya dilahirkan pada $613 \mathrm{M}$, yaitu 3 tahun sesudah masa Jahiliyah usai (pasca $610 \mathrm{M}$ ). Jika 'Âishah dilahirkan pada era Jahiliyah, seharusnya pada saat menikah, 'Âishah sudah berumur minimal 14 tahun.

Dengan demikian, al-Tabariy tidak memberikan informasi reliable mengenai umur 'Âishah ketika menikah, karena ada kontradiksi dalam riwayatnya.

b) Selisih Umur 'Âishah dengan Asmâ'

Menurut sebagian besar ahli sejarah, termasuk Ibnu Ḥajar al-Athqalâniy, ${ }^{44}$ 'Abd al-Raḥman bin Abî Zannad, ${ }^{45}$ dan Ibn Kathir, ${ }^{46}$ selisih umur Asma-anak perempuan tertua Abû Bakar- dengan 'Âishah adalah 10 tahun. Menurut Ibn Kathir dalam kitabnya al-Bidâyah wa al-Nihâyah, Asmâ' meninggal dunia pada 73 $\mathrm{H}$ dalam usia 100 tahun. $^{47}$ Dengan demikian pada awal Hijrah Nabi ke Madinah usia Asmâ' sekitar 27 atau 28 tahun ketika hijrah (622 M). Jika Asmâ' berusia 27

\footnotetext{
${ }^{42}$ Husein al-Zahabi, Mizân al-I'tidal (Pakistan: al-Maktabah al-Atriyyah, t.th), 210.

43 Aḥmad ibn Muhammad ibn Hạnbal Al-Syaibânî, Musnad Aḷmad ibn Hanbal (Beirut: Dâr al-Ihyầ al-Turâs al-'Arabî, t.th.), 210.

${ }^{44}$ Al-Tabari, Tarikh al Umam wa al-Mamlîk, Vol. 4 (Beirut: Dâr al-Fikr, 1979), 50.

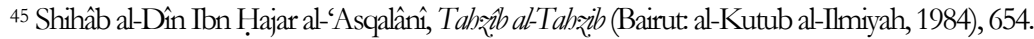

46 Al-Zahabi, Syyar al-A'lam al-Nubala', Vol. 2 (Beirut: Mu'assasah al-Risâlah, 1992), 289.

${ }^{47}$ Ibn Kathir, al-Bidâyah wa al-Nibâjah, Vol. 8 (Al-jizah: Dâr al-Fikr al-'Arabi, 1933), 372.
} 
atau 28 tahun ketika hijrah (ketika 'Âishah berumah tangga), 'Âishah seharusnya berusia 17 atau 18 tahun. Jadi, 'Âishah, berusia 17 atau 18 tahun ketika hijrah pada tahun dimana 'Âishah berumah tangga.

c) Selisih umur 'Âishah dengan Fatimah

Menurut riwayat Ibn Hajar, jika dihubungkan dengan umur Fạtimah, "Fạtimah dilahirkan ketika Ka'bah dibangun kembali, tepatnya, ketika Nabi SAW berusia 35 tahun, padahal Fatimah 5 tahun lebih tua dari 'Âishah". Fatimah lahir ketika Nabi berumur 30 tahun. Jika Nabi menikahi "Âishah setahun setelah hijrah (atau ketika Nabi berumur 53 tahun). Ini mengindikasikan 'Âishah berumur 17-18 tahun ketika menikah dengan beliau. ${ }^{48}$ Dengan demikian, antara riwayat Ibn Hajar, al-Ṭabari, Hishâm, dan Ibn Hambal terdapat kontradiksi satu sama lain. Tetapi tampak nyata bahwa riwayat 'Âishah menikah usia 7 tahun adalah mitos tak berdasar.

d) 'Âishah ikut berperang

Sebuah riwayat mengenai partisipasi 'Âishah dalam perang Badar dijabarkan dalam hadis Muslim. 'Âishah, ketika menceritakan salah satu momen penting dalam perjalanan selama perang Badar, mengatakan: "ketika kita mencapai shajarabl". perjalanan menuju Badar.

Begitu pula dengan riwayat mengenai pastisipasi 'Âishah dalam Uhud yang tercatat dalam Bukhâri "Anas mencatat bahwa pada hari Uhud, orang-orang tidak dapat berdiri dekat Rasulullah. Pada hari itu, saya melihat 'Âishah dan Ummi Sulaim dari jauh, Mereka menyingsingkan sedikit pakaiannya untuk mencegah halangan gerak dalam perjalanan tersebut., 50

Berdasarkan riwayat ini, 'Âishah ikut berada dalam perang Uhud dan Badar. Padalah dalam riwayat Bukhâri lainnya disebutkan bahwa: "Ibn Umar menyatakan bahwa Rasulullah tidak mengizinkan dirinya berpartisipasi dalam Uhud, ketika itu, Ibn Umar berusia 14 tahun. Tetapi ketika perang Khandaq, sudah berusia 15 tahun, Nabi mengijinkan Ibn Umar ikut dalam perang. Sedangkan 'Âishah ikut serta dalam perang Badar dan Uhud."

Jika anak-anak berusia di bawah 15 tahun akan dipulangkan dan tidak diperbolehkan ikut dalam perang, maka keikutsertaan ‘Âishah dalam perang Badar dan Uhud jelas mengindikasikan bahwa 'Âishah tidak berusia 9 tahun ketika itu, tetapi minimal berusia 15 tahun. Di samping itu, wanita-wanita yang ikut

\footnotetext{
48 Ibn Kathir, al-Bidâyah wa al-Nihâyah, Vol. 8, 371.

${ }^{49}$ Syihâb al-Dîn Ibn Hajar al-'Athqualânî, al-Isabah fi Tamyr̂̌ al-Sahabah, Vol. 4 (al-Riyâdh: Maktabah al-Riyâdh alHaditha, 1978), 377.

50 Abû 'Abd Allah Muhammad bin Isma’il bin Ibrahim bin al-Mughirah bin Bardizabah, Shahih Bukhari, Vol. III (Beirut: Dâr al-Kitab al-Ilmiyah, t.th), 172.

51 Abû 'Abd Allah, Shabih Bukhari; Vol. III, 172.
} 
menemani para pria dalam perang sudah seharusnya berfungsi untuk membantu, bukan untuk menambah beban bagi mereka. Ini merupakan bukti lain dari kontradiksi usia pernikahan 'Âishah.

e) 'Âishah dan turunnya surat al-Qamar

Menurut beberapa riwayat, 'Âishah dilahirkan pada tahun ke-8 sebelum hijriyah. Tetapi menurut sumber lain dalam Bukhâri, "Âishah tercatat mengatakan hal ini: "Saya seorang gadis muda (jarijah)" ketika surah al-Qamar diturunkan. ${ }^{52}$

Surat 54 dari Al-Qur'an tersebut diturunkan pada tahun ke-8 sebelum Hijriyah, artinya surat tersebut diturunkan pada tahun 614 M. jika 'Âishah memulai berumah tangga dengan Rasulullah SAW pada usia 9 di tahun $623 \mathrm{M}$ atau $624 \mathrm{M}$, berarti 'Âishah masih bayi yang baru lahir (sobijyab) pada saat surah al-Qamar diturunkan. Menurut riwayat di atas, secara aktual tampak bahwa 'Âishah adalah sudah menjadi gadis muda, bukan bayi yang baru lahir. ketika pewahyuan alQamar.

Jadi, 'Âishah, telah menjadi jarijab bukan sobijyah (bayi), atau telah berusia 6-13 tahun pada saat turunnya surah al-Qamar, dan oleh karena itu sudah pasti berusia 1421 tahun ketika dinikahi oleh Nabi SAW.

Berdasarkan keterangan di atas, pemahaman atas riwayat tentang usia pernikahan 'Âishah adalah 6 atau 9 tahun masih mengandung banyak persoalan, karena riwayat tersebut temyata kontradiktif dengan riwayat-riwayat lainnya. Dengan demikian, riwayat tentang usia pernikahan 'Âishah adalah 6 atau 9 tahun masih belum dapat dibuktikan kebenarannya. Sehingga hadis itu tidak dapat dijadikan dalil menikah di usia muda atau adanya hak j̈bâr wali nikah.

Ketiga, Penyimpulan penelitian matan. Setelah dilakukan analisis terhadap matan hadis riwayat 'Âishah yang ditakbrij oleh al-Bukhâri, maka dapat disimpulkan sebagai berikut; (a) matan hadis ternyata shâdh, karena bertentangan dengan dalil naqlij; dan (b) matan hadis tersebut terkena illat, karena bertentangan dengan dalil 'aqliy, dari aspek bahasa dan sejarah.

Dengan demikian dapat disimpulkan bahwa hadis riwayat 'Âishah yang ditakbrî oleh al-Bukhâri tersebut, berkualitas da'îf al-hadith. Dan para ulama sepakat tidak menggunakan hadis daîf sebagai dalil hukum, akan tetapi hanya boleh untuk fadâil ala'mâl (keutamaan amal). ${ }^{53}$

Melihat hasil takbrij al-hadith di atas, yang menyatakan bahwa hadis dasar j̈bâr adalah da'f, maka hadis tersebut tidak diperbolehkan sebagai dasar hukum. Akan tetapi, hanya boleh digunakan sekedar untuk fadâil al-a'mâl (keutamaan amal).

Jika dicermati lebih jauh lagi, pendapat Imam Shâffî̀ sudah tidak sesuai dengan keadaan sekarang, sebab kondisi sosialnya sudah berbeda. Perempuan pada masa

\footnotetext{
${ }^{52}$ Abû 'Abd Allah, Shabib Bukhari, Vol. III, 174.

${ }^{53}$ Mạ̣mûd al-Tahhận, Tayssir Mustalah al-Hadìth (Surabaya: al-Haramayn, t.th.), 65-66.
} 
Imam Shâfî̀ hanya dianggap sebagai barang dagangan, pemuas nafsu seks laki-laki dan tidak diperbolehkan untuk menduduki jabatan pemerintahan, bahkan akses keluar rumah sangat dibatasi, harus dengan muhrimnya.

Seiring dengan perkembangan dan perubahan sosial yang terus bergerak pada ranah global dan mondial, peran kaum perempuan semacam itu agaknya sudah jauh mengalami pergeseran. Asumsi ini diperkuat dengan gencarnya perjuangan kaum perempuan dalam upaya melakukan pembebasan "mitos" lama, emansipasi wanita, dan kesetaraan gender. Saat ini perempuan telah terlibat aktif dalam membangun bangsa dan negara melalui politik, ekonomi, sosial, budaya, pendidikan, bahkan keamanan. Bahkan kadang kaum wanita bisa tampil lebih mandiri, kreatif, penuh inisiatif, dan profesional dalam mengambil perannya tersebut. ${ }^{54}$

Dari kajian di atas dapat disimpulkan, tidak ada hak j̈bâr bagi kakek atau ayah pada perempuan janda atau gadis yang sudah dewasa (baligh), tetapi harus dengan persetujuannya. Sebab secara tekstual terdapat nas yang menyebutkan harus ada persetujuan dari perempuan yang dinikahkan. Sedang makna hadis yang menyatakan bahwa perempuan itu dinikahkan oleh ayahnya tidak berarti boleh memaksa.

Ada riwayat yang menjelaskan perempuan diperbolehkan memilih antara meneruskan perkawinan atau membatalkannya jika dinikahkan oleh orang tuanya dengan cara ̈̈bâr yaitu:

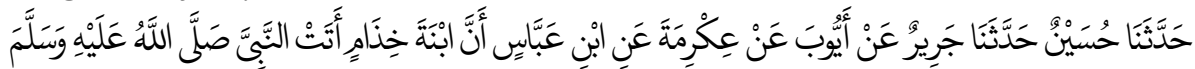

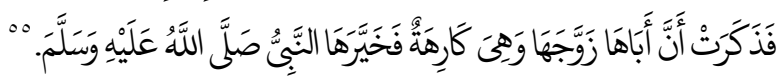

Artinya: Telah menceritakean kepada kami Husein, telah menceritakan kepada kami Jarir dari Ayyûb dari Tkrimah dari ibn 'Abbâs: Sesunggubnya anak perempuannya Kbidbâm mendatangi Nabi SAW kemudian menuturkan, sesungoubmya ia telab dinikabkean oleb ajahnya dan ia tidake menyukainya. Maka Nabi memberi kesempatan untuk. memilib (antara meneruskan atau membatalkan) (H.R. Ahmad: 2469).

Dengan melihat riwayat di atas, jelaslah bahwa ketika perkawinan dipaksakan akan mengurangi kemaslahatan. Mungkin juga bisa menimbulkan madhorot. Oleh karena itu, dalam riwayat di atas digambarkan bahwasanya Nabi SAW mempersilahkan kepada anak perempuannya Khidhâm untuk memilih (antara meneruskan atau membatalkan) bukan memaksa untuk mengikuti orang tuanya, guna menambah kemaslahatan yang akan diperoleh.

\footnotetext{
${ }^{54}$ Mahmmûd al-Ṭahhận, Taysîr Mustalah. al-Hadìth, 215-216.

55 Aḥmad bin Hanbal, Musnad al-Imâm Ałmmad bìn Hanbal, Vol. IV (t.tp: Muassasah al-Risâlah, 1999), Indeks 2469, 275.
} 


\section{Rekonstruksi Nalar Hukum Imam Shâfi'î tentang Hak Ijbâr Wali Nikah}

Hukum Islam dengan segala keunggulannya, merupakan aturan Tuhan yang bertujuan memberikan kebaikan dan kemudahan kepada umat manusia. Dengan demikian, hukum Islam mempunyai beberapa kekhasan yang tidak dimiliki oleh hukum manapun di dunia. Kekhasan tersebut diantaranya adalah sifatnya yang fleksibel. Adanya sifat fleksibel selain untuk kemudahan umat dalam mengaktualisasikan titah Tuhan, juga merupakan bentuk konkret dari humanitas hukum langit.

Ibnu Qayyim al-Jauziyah berpendapat dalam kitabnya I'lam al-Munaqqiîn. perubahan ide-ide atau pemikiran hukum dan perbedaannya sesuai dengan perubahan zaman, ruang, keadaan, niat dan kebutuhan. Bahkan lebih jauh beliau mengatakan bahwa tidak memahami atau mempertimbangkan perubahan merupakan kesalahan besar dalam syariat. ${ }^{56}$ Karena intinya, tujuan hukum yang ada dalam setiap ajaran (syariat) adalah untuk kemaslahatan umat itu sendiri, dan hukum Islam akan berperan secara nyata dan fungsional kalau ijthad ditempatkan secara proporsional dalam mengantisipasi dinamika sosial dengan berbagai kompleksitas persoalan yang ditimbulkannya.

Salah satu yang menarik untuk dicermati, bahwa dalam membentuk fikih Indonesia, Hasbi Ash-Shiddiqy menekankan pentingnya kesadaran dan kearifan untuk melakukan refleksi historis atas pemikiran hukum Islam pada masa awal perkembangannya. Dalam hal inilah Hasbi mengkonsepsikan bahwa mempertimbangkan kehadiran tradisi (unf) setempat sebagai acuan pembentukan sebuah format hukum Islam baru menjadi satu keniscayaan. Konsepsi ini dilandasi oleh pemikiran egalitarianisme ${ }^{57}$ Islam yang berkonsekuensi bahwa semua $" m f^{58}$ dalam masyarakat dapat dijadikan sumber hukum. Dengan demikian hal ini menafikan 'uf dari masyarakat Arab saja yang bisa menjadikan podasi dalam perumusan hukum. Bagi Hasbi, semua 'uf selama tidak bertentangan dengan prinsip ajaran Islam dan dalam batas-batas tertentu dapat diterima sebagai sumber hukum Islam.

Hal ini telah dilakukan oleh Imam Shâfiî dengan melahirkan sebuah ijtihad yang dikenal dengan istilah qaul qadim dan qaul jadid. Lahimya pemikiran ini dikarenakan masyarakat dengan berbagai dinamika yang ada menuntut adanya perubahan sosial, dan setiap perubahan sosial pada umumnya meniscayakan adanya perubahan sistem nilai dan hukum. Sebagaimana Zaenuddin mengutip pendapat Marx Weber dan

\footnotetext{
${ }^{56}$ Ibn Qayyim al-Jauziyah, I'lam al-Munvaqqièn an Rab al-'Allamîn, Vol. III (Bairut: Dâr al-Fikr, t.th.), 14.

${ }^{57}$ Egalitarianisme adalah ajaran bahwa manusia yang berderajat sama memiliki takdir yang sama pula. Pius A Partanto dan M Dahlan Al Barry, Kamus Immiah Populer, ..., 129.

58 Urf merupakan adat kebiasaan yang dipandang baik oleh akal dan diterima oleh tabiat manusia yang sejahtera. Nourouzzaman Shiddiqi, Fiqh Indonesia: Penggagas dan Gagasannya (Yogyakarta: Pustaka Pelajar, 1997), 122.
} 
Emile Durkheim menyatakan bahwa hukum merupakan refleksi dari solidaritas yang ada dalam masyarakat. ${ }^{59}$

Mencermati pembahasan di atas, maka dapat ditarik kesimpulan bahwa dalam membuat hukum Islam yang memiliki kesesuaian dengan tempat dan waktu adalah

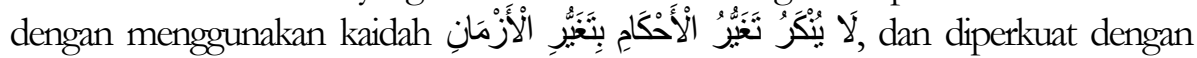
metode maslabah, dan metode 'inf.

Kaidah tersebut memiliki makna tidak bisa dipungkiri bahwa perubahan hukumhukum syari'at itu disebabkan oleh perubahan beberapan zaman. Ruang lingkup penyebab perubahan sebenamya tidak hanya masa, akan tetapi juga tempat dan keadaan yang mengitarinya. ${ }^{60}$ Perubahan yang dimaksud adalah yang berhubungan dengan muamalah (transaksi) bukan ibadah. Perubahan tersebut dititik tekankan pada perubahan kemaslahatan, tradisi dan adat istiadat. ${ }^{61}$

Permasalahan hak j̈bâr sangat erat kaitannya dengan masalah perkawinan yang oleh ulama' dikategorikan sebagai akad atau ikatan yang melibatkan antara pihak suami dan pihak istri. Adanya hubungan yang bersifat horisontal ini mengindikasikan bahwa urusan perkawinan sebenarnya masuk dalam urusan mu'amalah dunyâwiyah, meskipun juga tetap akan berdampak pada urusan ukrâuryjah. Namun yang hendak diungkapkan di sini, perkawinan bukanlah termasuk dalam katagori ibadah mahdah yang bersifat sakral, tetapi merupakan mu'amalah yang bersifat profan. Oleh karenanya, sudah seyogyanya dipahami juga bahwa permasalahan hak j̈bâr masuk dalam katagori mu’amalah yang menganut sebuah kaidah berbunyi:

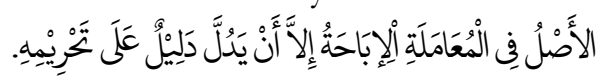

Artinya: Hukum asal dalam semua bentuk mu'amalah adalab boleb dilakukean, kecuali ada dabl yang mengharamkanmy . $^{62}$

Dengan redaksi yang sedikit berbeda, namun dengan maksud yang sama dengan kaidah di atas, terdapat pula kaidah yang berbunyi:

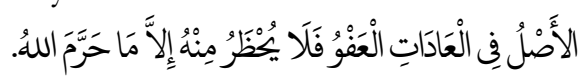

Artinya: Hukum asal dalam adat adalah pemaafan, tidak ada yang diharamkan kecuali apa yang diharamkan Allah $S W T^{63}$

Dalam hal ini, menurut penulis hak j̈bâr bukan dalam ranah mendasar atau pokok ajaran Islam. Sebab, hak j̈bâr didasarkan pada hadis perkawinan 'Âishah di atas.

\footnotetext{
59 Zaenuddin, "Hukum Islam dan Perubahan Social (Menyelaraskan Realitas dengan Maqashid al-Syariah)", dalam Media Bina Ilmiah, Vol. VI, No. 6, Desember 2012, 18.

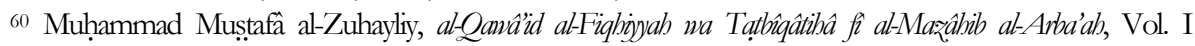
(Damaskus: Dâr al-Fikr, 2006), 356.

61 'Âbid bin Muhammad al-Sufyâniy, al-Thjyâb wa al-Shumuil fỉ al-Shari’ah al-Islâminyah (Makkah: Maktabah alManarah, 1988), 448.

62 Terjemah diambil dari A. Djazuli, Kaidah-Kaidab Fikih (Jakarta: Kencana, 2014), 130.

${ }^{63}$ A. Djazuli, Kaidah-Kaidab Fikih, 130.
} 
Dalam hadis tersebut tidak ada lafad/kata yang menunjukkan larangan atau perintah, hanya sebuah kabar Rasul menikahinya pada umur 6 tahun dan berumah tangga umur 9 tahun. Lafad/kata yang menunjukkan perintah dan larangan biasanya dalam bentuk amar dan nabi atau nafi. Kalau selain ini, jarang ditemukan.

Hak äbâr masuk ranah ijtihâdijyah. Maksudnya, hukum yang berdasarkan pada qijâs atau kemaslahatan. Sebab dasar yang di pakai Imam Shâfî̀ hanyalah eksplisit. Dan beliau menetapkannya beralasan karena kemaslahatan anak perempuan. Oleh karena itu, hukum ini bisa diubah yang disesuaikan dengan masa, tempat dan keadaan.

Salah satu kaidah fikih menyebutkan bahwa hukum itu bersandar pada illatnya. Kaidah tersebut berbunyi:

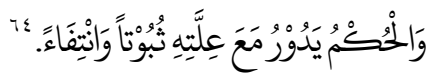

Artinya: Hukum itu bersandarpada illatnya, ada dan tidaknya (illat).

Terkait hal ini terdapat sebuah kaidah yang berbunyi:

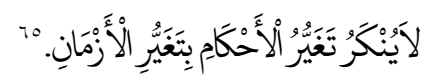

Artinya: Tidak dapat dipungkiriperubahan bukum disebabkan perubahan raman.

Hadits riwayat Ibn 'Abbâs di atas ${ }^{66}$ yang menjelaskan tentang hilangnya kemaslahatan jika perkawinan dipaksa adalah dasar dijadikan pelarangan j̈bâr bagi ayah maupun wali terhadap anak perempuan atau janda yang sudah dewasa, karena hadis lain menyebutkan untuk meminta persetujuan kepada anak perempuan atau janda. ${ }^{67}$

Berkaitan dengan pernikahan gadis dibawah umur, ada pendapat menarik yang dikemukakan oleh Ibn Shibrimah, "mengawinkan anak gadis di bawah umur tidak sah, demi kemaslahatan anak gadis yang bersangkutan, juga keluarga." ${ }^{, 8}$ Pendapat ini memberikan tuntutan rasional bahwa yang akan menjalani rumah tangga adalah anak perempuannya, maka seorang ayah atau kakek harus memberikan kesempatan kepada anak gadisnya untuk tumbuh dan berkembang menjadi orang dewasa yang dapat memilih jalan hidupnya serta menentukan jodohnya. Perkawinan hendaknya dilangsungkan setelah masing-masing mencapai taraf kematangan, baik secara fisikbiologis maupun mental-psikologis.

Dengan menggunakan dalil tersebut, jelaslah bahwa seorang ayah atau kakek dilarang untuk memaksa anak gadis dalam ranah perkawinan.

Kemaslahatan di atas sama sekali tidak bertentangan dengan tindakan-tindakan shara', sebab berdasarkan pada hadis yang diriwayatkan oleh Imam Ahmad bin

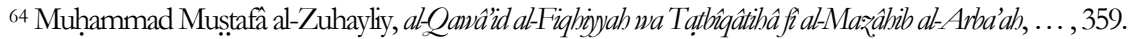

${ }^{65}$ Muhạmmad Sidqî Ibn Aḥmad al-Burnû, al-Wajiž (Riyad: Maktabab al-Tawbah), 255.

${ }^{6}$ Yaitu hadits

${ }^{67}$ Shams al-Dîn al-Sharhashiy, al-Mabsụt, Vol. V (t.tp: Dâr al-Fikr, t.th), 2.

${ }^{68}$ Wahbah al-Zuhayliy, al-Fiqh al-Islam wa Adillatuh, Vol. 7, 189.
} 
Hanbal. Dan kemaslahatan ini juga termasuk ke dalam kategori maslabah al-dharîrijyah, sebab demi melindungi agama, jiwa, akal, harta, dan kehormatan.

Kemaslahatan ini untuk melindungi: (1) agama, maksudnya agama adalah satusatunya aturan yang harus dianut oleh umatnya. Jika agama memberatkan dan menyakitkan pasti agama akan ditinggalkan oleh pengikutnya. (2+3) Jiwa dan Akal, jika perkawinan dipaksa dan nyatanya calon pengantin tidak suka, maka ditakutkan kesehatan jiwa dan akalnya akan menurun. (4+5) Harta dan Kehormatan, bisa dipastikan jika perkawinannya rusak harta juga akan terkikis, tidak hanya itu kehormatan keluarga juga akan terkena dampaknya.

Perlu juga diperhatikan, kebiasaan perempuannya juga berbeda. Perempuan pada zaman Imam Shâfî̀, sampai awal kemerdekaan Indonesia hanya hidup untuk menjadi ibu rumah tangga, tidak diperbolehkan melakukan aktifitas selain di lingkungan rumah. Terkadang, lebih parahnya lagi, wanita hanya digunakan sebagai alat pemuas nafsu belaka, ada yang sampai dianggap sebagai barang dagangan.

Kebiasaan kaum perempuan pada zaman sekarang sudah diperbolehkan untuk mengikuti pendidikan, memiliki jabatan bahkan bekerja. Tidak asing lagi gaji istri bisa mencukupi kebutuhan keluarga, banyak pula istri yang menjadi tulang punggung rumah tangga. Kegiatannya juga sudah memasuki ranah publik. Pembangunan bangsa tidak hanya didominasi oleh laki-laki, kaum perempuan juga banyak berjuang di wilayah pendidikan, ekonomi, budaya, bahkan keamanan. Terlihat mereka banyak yang mengikuti kegiatan-kegiatan organisasi perempuan, seperti PKK, Muslimat, dan Aisyiah.

Kebiasaan atau' 'uffadalah:

Artinya: Kebiasaan mayoritas kaum baik dalam perkeataan dan perbuatan.

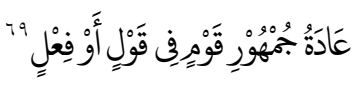

Oleh karena itu, dengan melihat kebiasaan yang sudah berbeda sangat jauh, ayah atau kakek dilarang untuk memaksa anak gadisnya dalam perkawinan. 'unf tersebut dapat dijadikan dalil hukum shara' karena: (a) 'uf bisa berlaku secara umum. (b) 'uff telah memasyarakat ketika persoalan yang akan ditetapkan hukumnya itu muncul. Dan (c) 'uf tidak bertentangan dengan nas. ${ }^{70}$

Dari sudut pandang perkawinan dalam undang-undang Perkawinan No. 1 Tahun 1974, sebagai hukum positif Indonesia, yang mengatur perkawinan tentang usia pasangan pengantin, bagi laki-laki usia 19 dan perempuan usia 16, kemungkinan kecil j̈bâr bisa dilaksanakan. Namun hak j̈bâr masih sering dilakukan oleh masyarakat, maka perlunya memberikan pemahaman baru pada masyarakat bahwa $\ddot{j b a ̂ r ~ b u k a n ~}$

\footnotetext{
69 Aḥmad Fahmi Abû Sunnah, al-Uyf wa al-'Adah fi Ra'y al-Fuqaha' (Mesir. Dâr al-Fikr al-'Araiy, t.th.), 8. Muhammad Aḥmad al-Zarqa', al-Madkhâl 'alâ al-Figh al-ÁAm, Vol.II (Beirut: Dâr al-Fikr, 1968), 840.

${ }^{70}$ Izz al-Dîn ibn 'Abd al-Salam, Qawväid al-A Ahkâm fi Masậl al-Anâm, Vol. II (Beirut: Dâr al-Kutub al-llmiyyah, t.th.), 178 .
} 
hak sepenuhnya orang tua. Oleh karena itu, dalam perkawinan terdapat hal-hal yang perlu diperhatikan: (a) Orang tua membekali anak-anaknya dengan membekali ajaran agama, dan memberikan wawasan yang luas dalam memilih pasangan hidup nanti, agar benar-benar dipahami secara matang. (b) Mengawinkan anaknya hendaknya dilangsungkan setelah masing-masing mencapai taraf kematangan, baik secara fisikbiologis maupun mental-psikologis, karena menikah di bawah umur bisa mematikan keberlangsungan hidup anak. (c) Adanya kompromi dan hubungan atau komunikasi dua arah yang harmonis antar pasangan pengantin maupun antar kedua orang tua pasangan pengantin. Dan (d) dalam perkawinan dibutuhkan keikhlasan dan keridlaan dari orang tau dan anak serta keluarga, karena persoalan perkawinan bukan semata persoalan kedua orang tua, akan tetapi merupakan kemaslahatan keluarga, tanpa pemaksaan dan kekerasan.

Dari semua penjelasan di atas dapat ditarik kesimpulan bahwasanya hak $\ddot{j} b a ̂ r$ wali nikah sudah tidak layak dipraktikkan, terlebih di Negara Indonesia. Oleh karena itu, orang tua atau wali harus mempertimbangkan kemaslahatan yang lebih besar, yaitu tidak adanya hak j̈bârwali nikah bagi anak perempuan.

\section{Kesimpulan}

Imam Shâfiî̀ merumuskan hak ̈̈bâr wali nikah dengan sangat terperinci. Hak j̈bâr secara terminologi adalah hak ayah atau kakek untuk menikahkan anak perempuannya, tanpa harus mendapatkan persetujuan atau izin terlebih dahulu dari anak perempuan yang akan dinikahkan tersebut, asalkan ia bukan seorang janda. Berdasarkan pada hadis yang menceritakan perkawinan Rasul dengan 'Âishah putri Abû Bakr RA.

Seorang ayah atau kakek dilarang untuk memaksa anak gadis dalam ranah perkawinan. Karena mengandung kemaslahatan, yaitu untuk melindungi agama, jiwa, akal, harta dan kehormatan. Serta kebiasaan perempuannya berbeda. Zaman Imam Shâfiî, bahkan sampai awal kemerdekaan Indonesia hanya hidup untuk menjadi ibu rumah tangga, tidak diperbolehkan melakukan aktifitas selain di lingkungan rumah. Sekarang, sudah diperbolehkan untuk mengikuti pendidikan, memiliki jabatan bahkan

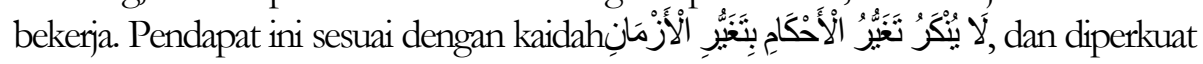
dengan metode maslabah dan 'uf. 


\section{Daftar Pustaka}

'Asqalânî (al), Shihâb al-Dîn Ibn Hajar. Al-Isabah fi Tamyî̀ al-Sababah. Riyâdh: Maktabah al-Riyâdh al-Haditha, 1978. .Fath al-Bari Syarh Shabih Muskim. Beirut: Dâr Marifah, 1379 H.. - Tabə⿱b al-Tahrib. Bairut: al-Kutub al-Ilmiyah, 1984.

A. Djazuli. Kaidah-Kaidab Fikih. Jakarta: Kencana, 2014.

Bardizabah, Abû 'Abd Allah Muhammad bin Isma’il bin Ibrahim bin al-Mughirah bin. Shabih Bukhari. Beirut Dâr al-Kitab al-Ilmiyah, t.th.

Bustiy (al), Muhammad bin Hịbbân bin Aḥmad Abû Hatû̀m al-Tamîmiy. Al-Thiqât. Bairut: Dâr al-Fikr, 1975.

Damanhuri. Ijtihad Hermeneutis. Yogyakarta: IRCiSoD, 2016.

Ghazâliy (al), Abû Hamid. Al-Mushtasfâ fì Ilm al-Usûul. Beirut. Dâr al-Kutub alIslâmiyyah, 1993.

Hanbal, Aḥmad bin. Musnad al-Imâm Ałmmad bin Hanbal. t.tp: Muassasah al-Risâlah, 1999.

Haq, Husnul. 'Reformulasi Hak Ijbar Dalam Tantangan Isu Gender Kontemporer', dalam Jumal PAL ASTREN, No. 1, Juni 2015.

Hidayat, Taufiq. "Rekonstruksi Konsep Ijbar", dalam De Jure Jumal Syariah Dan Hukum, No. 1 Agustus 2009, STAI An-Nawawi Purworejo.

Jauziyah (al), Ibn Qayyim. I'lam al-Minvaqqiîn an Rab al'Âlaminn. Bairut. Dâr al-Fikr, t.th.

Jazîriy (al), 'Abd al-Raḥman. Al-Fiqh 'alâ Madzaabib al-Arba'ah. Beirut: Dâr al-Fikr, 1999. Kathir, Ibn. Al-Bidâyah wa al-Nihâyah. Al-jizah: Dâr al-Fikr al-'Arabi, 1933.

Kûfiy (al), Ahmad bin 'Abd Allah bin Sâliḥ Abû al-Hasan al-'Ajaliy. Ma'rifah al-Thiqât. Madînah: Maktabah al-Dâr.

Ma'luf, Lous. Al-Mumiñd Fî al-L noot wa al-A'lam. Beirut: Dar al-Masyrik, 1968.

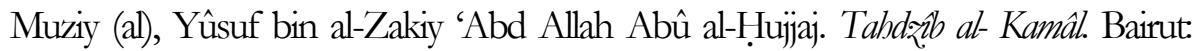
Muassisah al-Risâlah, 1980.

Nawâwiy (al), Abû Zakariyâ Yahyâ bin Sharaf. Shaṛ̣ Sabị̂h Muslim. Beirut: Dâr Ihyầ Turâth al-Arâbiy, $1392 \mathrm{H}$.. Tabdrî̧ al-Asmâ. t.tp: t.p, t.th.

Nîsabûrî (al), Muslim Ibn Hajjaj al-Qusyairî. Sabîh Muslim. Mesir. al-Mạtba’ah alMișriyah, $1349 \mathrm{H}$.

Ritonga, Iskandar. Hak-Hak W anita dalam Putusan Peradilan Agama. Jakarta: Program

Peningkatan Kualitas Pelayanan Publik Ditjen Bimas Islam dan Penyelenggaraan Haji, 2005.

Salam (al), 'Tzz al-Dîn ibn 'Abd. Qawaì al-Aḥkâm fi Masậl al-Anâm. Beirut: Dâr alKutub al-Ilmiyyah, t.th.. 
Shâffii (al), Abû 'Abd Allah Muhammad bin Idris. Al-Umm. Beirut: Dâr al-Fikr, t.th. Sharhashiy (al), Shams al-Dîn. Al-Mabsụt. t.tp: Dâr al-Fikr, t.th..

Shiddiqi, Nourouzzaman. Fiqh Indonesia: Penggagas dan Gagasannya. Yogyakarta: Pustaka Pelajar, 1997.

Subhan, Zaitunah. Peningkatan Kesetaraan \& Keadilan Jender Dalam Membangun Good Govermance. Jakarta: el-Kahfi, 2002.

Sufyâniy (al), 'Âbid bin Muhammad. Al-Thìjâb wa al-Shumûl fî al-Shariah al-Islâminyah. Makkah: Maktabah al-Manarah, 1988.

Sunnah, Aḥmad Fahmi Abû. Al-Urf wa al'‘Adah fi Rajy al-Fuqaha'. Mesir: Dâr al-Fikr al-Araiy, t.th..

Ṭaḥân (al), Maḥmûd. Taysîr Mustalah al-Hadîth. Surabaya: al-Haramayn, t.th..

Tabari (al). Tarikh al Umam wa al-Mamluk.. Beirut: Dâr al-Fikr, 1979.

Wahid, Marzuki. Fiqh Indonesia. Cirebon: ISIF, 2014.

Wahyuni Shifatur R. Mengkritisi Hadis-Hadis Tentang Usia Pernikahan Aisyah, dalam Musawa Jurnal Studi Gender dan Islam, No. 2, Juli 2009. Yogyakarta: UIN Sunan Kali Jaga, 2009.

Zaenuddin. "Hukum Islam dan Perubahan Social (Menyelaraskan Realitas dengan Maqashid al-Syariah)", dalam Media Bina Ilmiah, No. 6, Desember 2012.

Zahabi (al), Husein. Mizân al-I'tidal. Pakistan: al-Maktabah al-Atriyyah, t.th.

Zahabi (al). Syyar al-A'lam al-Nubala'. Beirut: Mu'assasah al-Risâlah, 1992.

Zarqa' (al), Muhammad Aḥmad. Al-Madkhâl 'alâ al-Figh al-'Âm. Beirut: Dâr al-Fikr, 1968.

Zuhayliy (al), Muhammad Muștafâ. Al-Qawâid al-Fiqhiyyah wa Tạtbîâatihâ fí al-Mazâhib al-Arba'ah. Damaskus: Dâr al-Fikr, 2006.

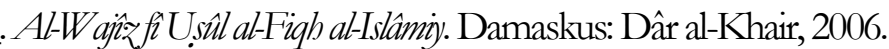

Zuhayliy (al), Wahbah. Al-Figh al-Islam wa Adillatuh. Beirut: Dâr al-Fikr, 1997. 